\title{
АРХЕОЛОГІЯ
}

УДК 902 (477.75)

DOI: https://doi.org/10.33782/eminak2019.3(27).309

\section{ВОДОСБОРНАЯ ЦИСТЕРНА ЭЛЛИНИСТИЧЕСКОГО ВРЕМЕНИ С ПОСЕЛЕНИЯ ВИЛИНО (РАССАДНОЕ) - КАК ПОГРЕБАЛЬНОЕ СООРУЖЕНИЕ ПОЗДНЕСКИФСКОЙ КУЛЬТУРЫ}

\author{
Геннадий Медведев \\ Институт археологии Крыма (Симферополь, Автономная Республика Крым) \\ e-mail: medvedgen@gmail.com \\ ORCID: https://orcid.org/0000-0003-0977-8321
}

\begin{abstract}
У статті охарактеризовано водозбірну цистерну з поселення Віліно (Розсадне) з Південно-Західного Криму. Споруда використовувалася під час функціонування садиби - $з$ кінця IV - до початку III cm. до н.е. Поселення входило до складу хори Херсонеса. У кінці II початку I cm. до н.е. на поселенні з'являється населення пізньоскіфської культури. 3 цього часу і до кінця II cm. н.е. - а можливо до першої половини III cm. н.е., об'єкт використовується як похоронна споруда.

У цистерні виявлені останки близько 30-ти кістяків, а також фрагменти інвентарю характерного для пізньоскіфської культури Передгірного Криму. Пізніше воно було пограбовано, а після використовувалося як підвальне приміщення.
\end{abstract}

Ключові слова: водозбірна цистерна, похоронна споруда, архітектура

Поселение Вилино (Рассадное)* расположено на обрывистом мысу левого берега р. Альмы, в 3,5 км выше ее устья и в 1,0 км к юго-западу от окраины с. Вилино Бахчисарайского района (рис.1). До 1992 г. в литературе памятник не упоминается. В 1990 г. в ходе разведок были определены границы памятника, хронология и этнокультурная принадлежность ${ }^{1}$.

Цитадель поселения занимает площадь около 5 тыс. м. ${ }^{2}$ и укреплена рвом и валом. Размеры укрепления составили $70 x 70$ м, глубина рва - 1,2 м, ширина - сверху 8,5 м, по дну - 4,5 м. Ширина вала была около 10 м, а высота около 1,0 м. Значительная часть площади укрепления, а также верхние слои поселения, уничтожены плантажной вспашкой. В настоящее время территория памятника задернована, часть его занимают остатки миндалевого сада².

\footnotetext{
* Привязка к ближайшему населенному пункту (Рассадное), от которого сохранилось несколько нежилых домов. Это обусловлено необходимостью более точно локализовать памятник, поскольку у юго-восточной окраины с. Вилино есть еще одно поселение - Бурлюк.

${ }^{1}$ Колтухов С.Г., Зубар В.М., Миц В.Л. Новий район хори Херсонеса елліністичного періоду // Археологія. 1992. № 2. С. 86-91.

${ }^{2}$ Архив Крымского филиала института археологии НАН Украины. Пуздровский А.Е., Медведев Г.В., Труфанов А.А. Отчет об охранных исследованиях поселения Вилино (Рассадное) в 2008 г. Инв. 6. № 1291. П. 1644. С. 4
} 


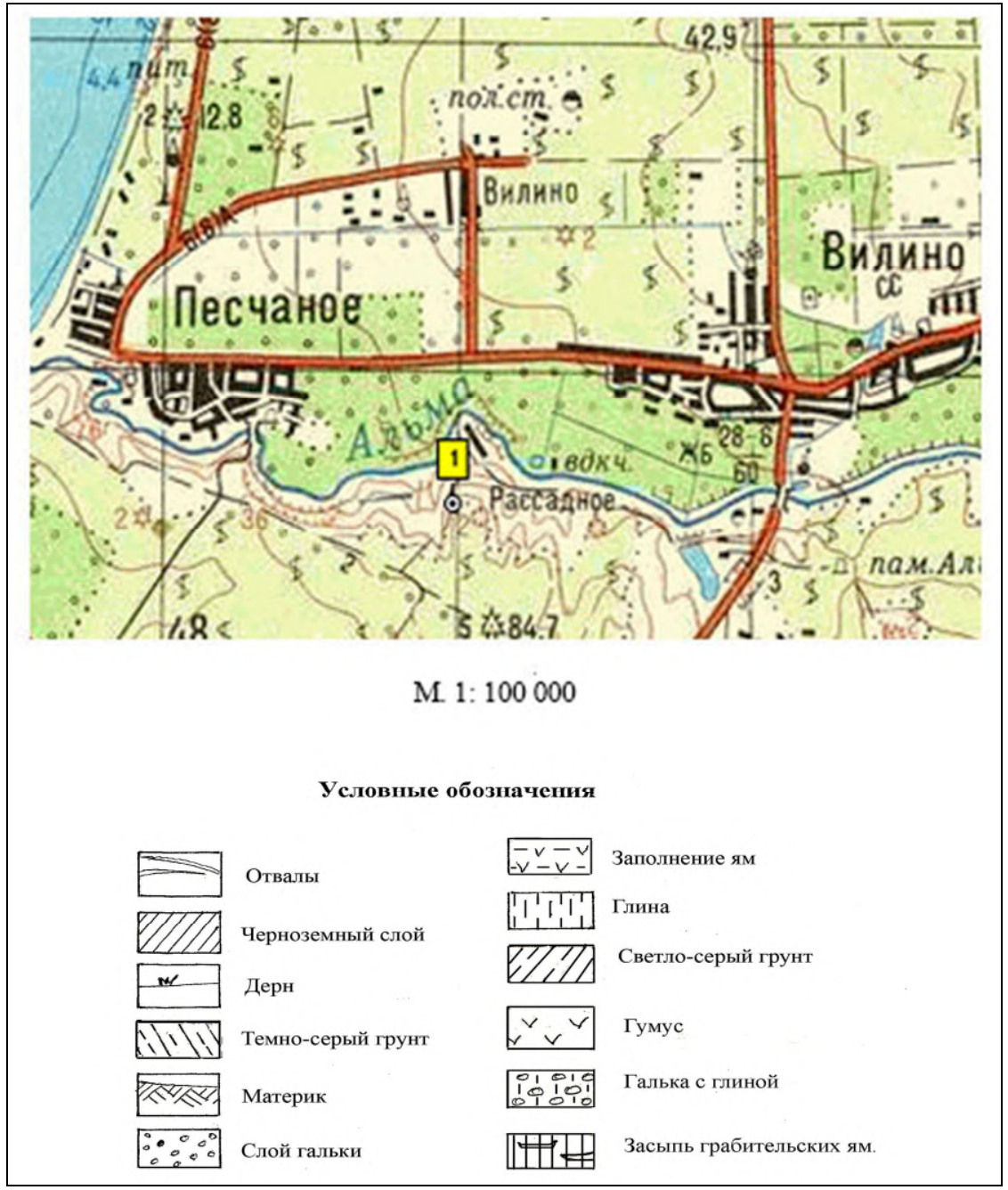

Puc. 1. Географическое положение поселения Вилино (Рассадное). Бахчисарайский район, Крым

В 2008 г. на поселении Вилино (Рассадное) было исследовано** каменное монументальное сооружение, построенное в классических традициях древнегреческой архитектуры ${ }^{3}$. Оно расположено к северо-востоку от разведочного раскопа 1990 г. на глубине 1,1-1,2 м от уровня современной поверхности (рис. 2). Сооружение представляло собой цистерну для сбора и хранения дождевой воды. Как показали дальнейшие исследования, она находилась у восточной стены усадьбы, внутри двора. В

\footnotetext{
3 Крыжицкий С.Д. Архитектура античных городов Северного Причерноморья: монография. Киев: Наукова думка, 1993. С. 62-64.

** Исследования проводились Альминской экспедицией КФ ИА НАНУ по открытому листу на имя А.Е. Пуздровского.

4 Пуздровский А.Е., Медведев Г.В., Ляшук П.М., Охранные исследования на городище Вилино (Рассадное) // Археологічні дослідження в Україні 2010. Київ-Полтава, 2011. С. 281; Пуздровский А.Е., Ляшук П.М., Масюта Д.А., Медведев Г.В. Охранные исследования на городище Вилино (Рассадное) // Археологічні дослідження в Україні 2012. Київ, 2013. С. 81.

*** Иллюстрации архитектуры к отчету подготовлены А.А. Труфановым.
} 
позднескифское время она вторично использовалась в качестве погребального сооружения (склепа). Затем склеп был ограблен и засыпан переотложенным культурным слоем с поселения. Попытки ограбления объекта предпринимались неоднократно, о чем свидетельствуют перекопы, как древние, так и современные.

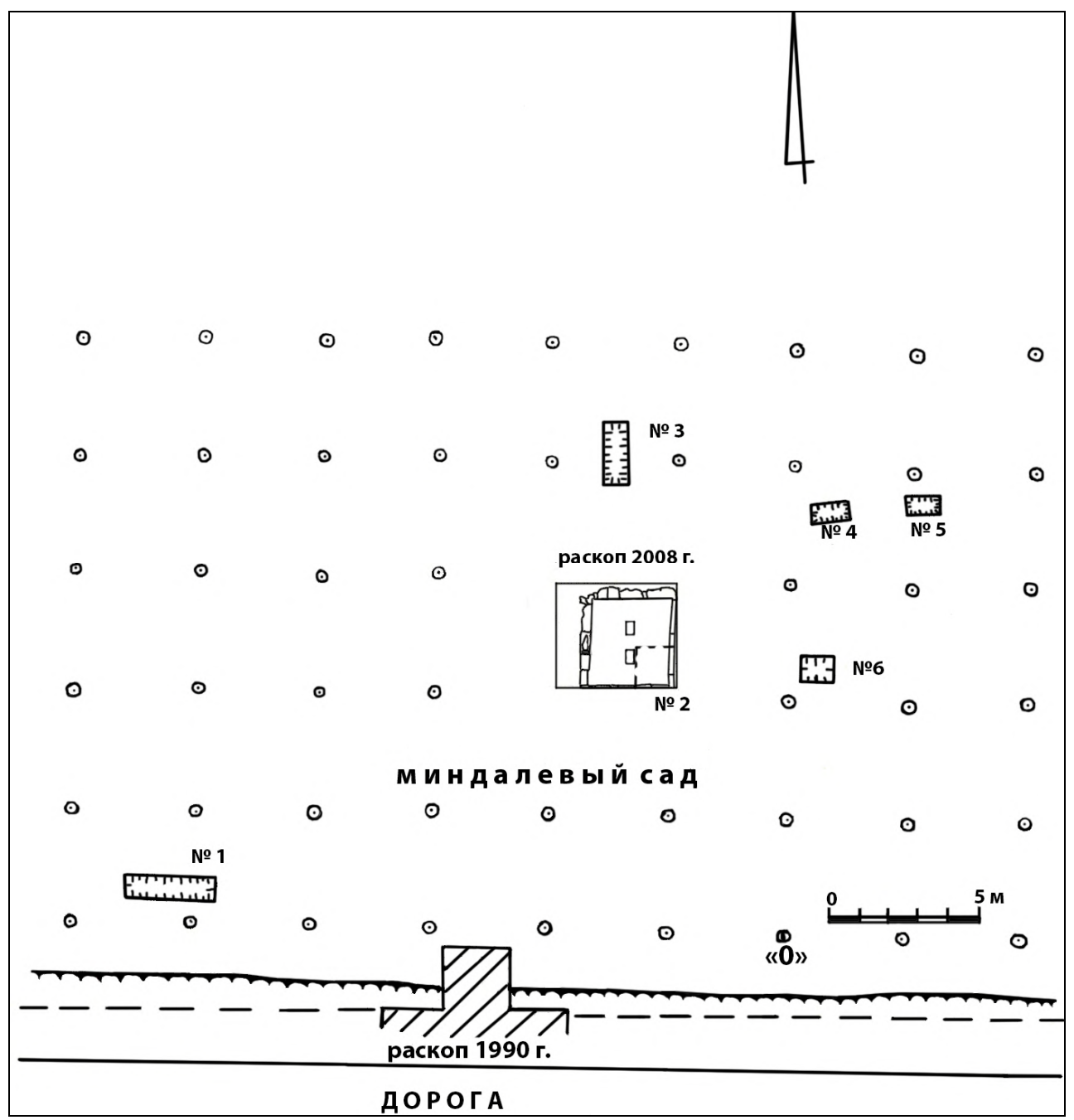

Puc. 2. Схематический план поселения Вилино (Рассадное) с водосборной цистерной, грабительскими шурфами (2007-2008 гг.) и раскопом 1990 г.

\section{Архитектура цистерны ${ }^{* * *}$.}

Каменная конструкция (цистерна) квадратной, в плане, формы. Ее размеры составили: в верхней части 2,85х2,65 м, в нижней - 3,35х3,2 м, глубина 4,2-4,35 м, что соответствует объему примерно около $24 \mathrm{~m}^{3}$. Сооружение ориентировано по сторонам света (рис. 3). Стены имеют отрицательный угол, и отклонение от вертикали составляет 0,3-0,4 м (рис. 6, I). Для перевязки кладок использовались камни Гобразной формы. Кладка выполнена на известковом растворе, камни тщательно оттесаны и швы подогнаны. Дно и стены цистерны в древности были оштукатуре- 
ны известковым (гидроизоляционным) раствором. Штукатурка сохранилась на полу и в отдельных местах на стенах, хорошо заглажена светло-серого цвета, толщиной 0,3-0,5 см. Дно сооружения незначительно понижается от стен к центру (4,24,35 м). В центре конструкции, по оси север-юг, были установлены две монолитные колоны прямоугольной формы высотой 2,25 (южная) и 2,7 м (северная), размеры в сечении составили $0,45 \times 0,3$ м. Они опирались на базы ступенчатой формы, которые были заглублены в дно сооружения. Размеры баз составили $0,65 x 0,50$ и 0,60х0,45 м, а высота их 0,2 м - от уровня пола. В юго-западной части цистерны в полу, находилась яма (отстойник) овальной формы 0,8x0,55 м. Пол в юго-восточном углу частично поврежден при ограблениях (рис. 3 , II).
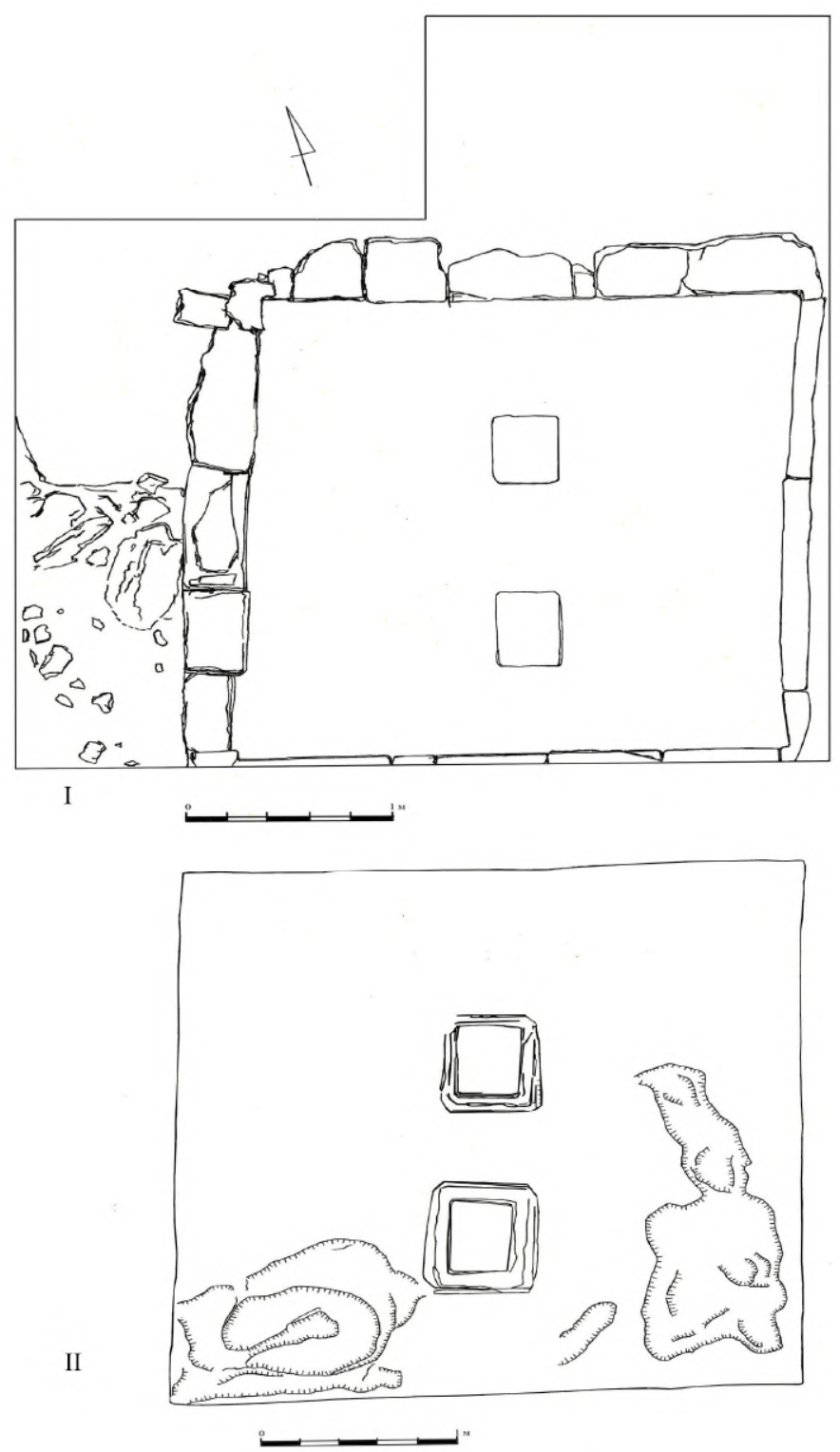

Pис. 3. План раскопа с цистерной: I - верхний уровень; II - нижний уровень 


\section{Описание северной стены.}

Длина кладки составила: в верхней части 2,6 м, в нижней 3,1 м, толщина 0,4 м, а высота 2,9-3,1 м. Кладка однослойная однолицевая, сложенная в орфостатной сложной системе, прослежено 7 рядов. Третий и седьмой ряды выполнены в постелистой системе. Блоки известняка хорошо обработаны и имели размеры от 0,2-0,5 х 0,6 м до $1,4 \mathrm{x} 0,7$ м. Камни в нижних рядах больших размеров, чем в верхних рядах кладки. В северной части стены сверху, сохранился участок известковой штукатурки размером $1,5 \times 1,4$ м и толщиной 0,3 см (рис. 4, I).

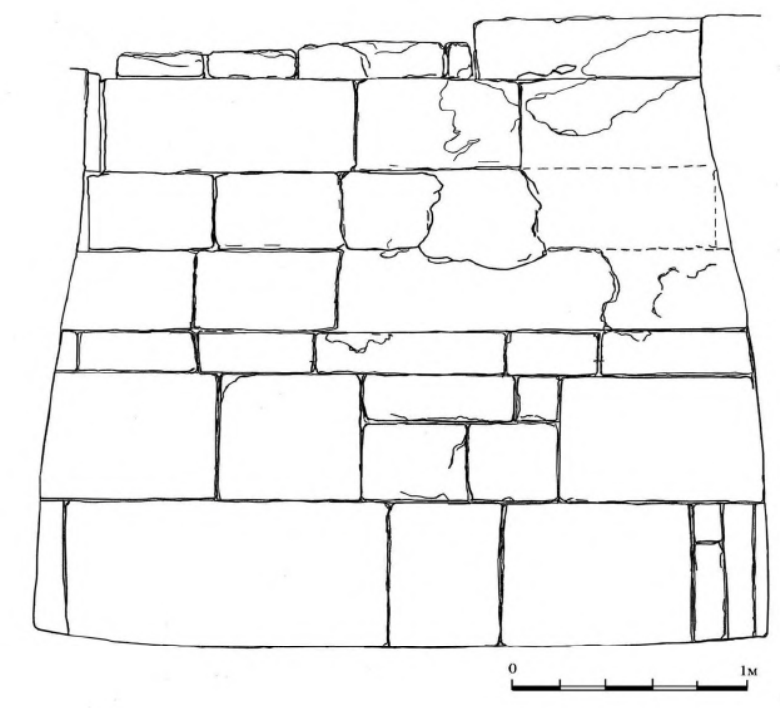

I

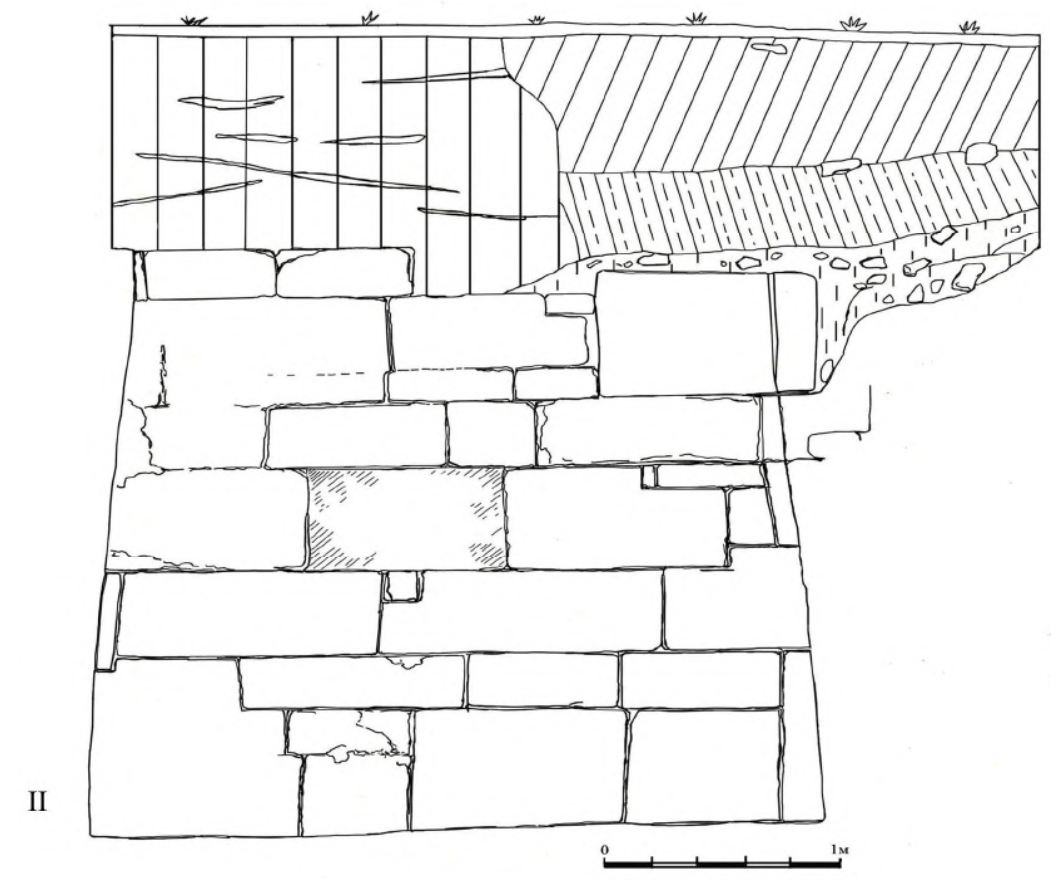

Puc. 4. Фасировка стен цистерны: I - северной; II - южной со стратиграфией 

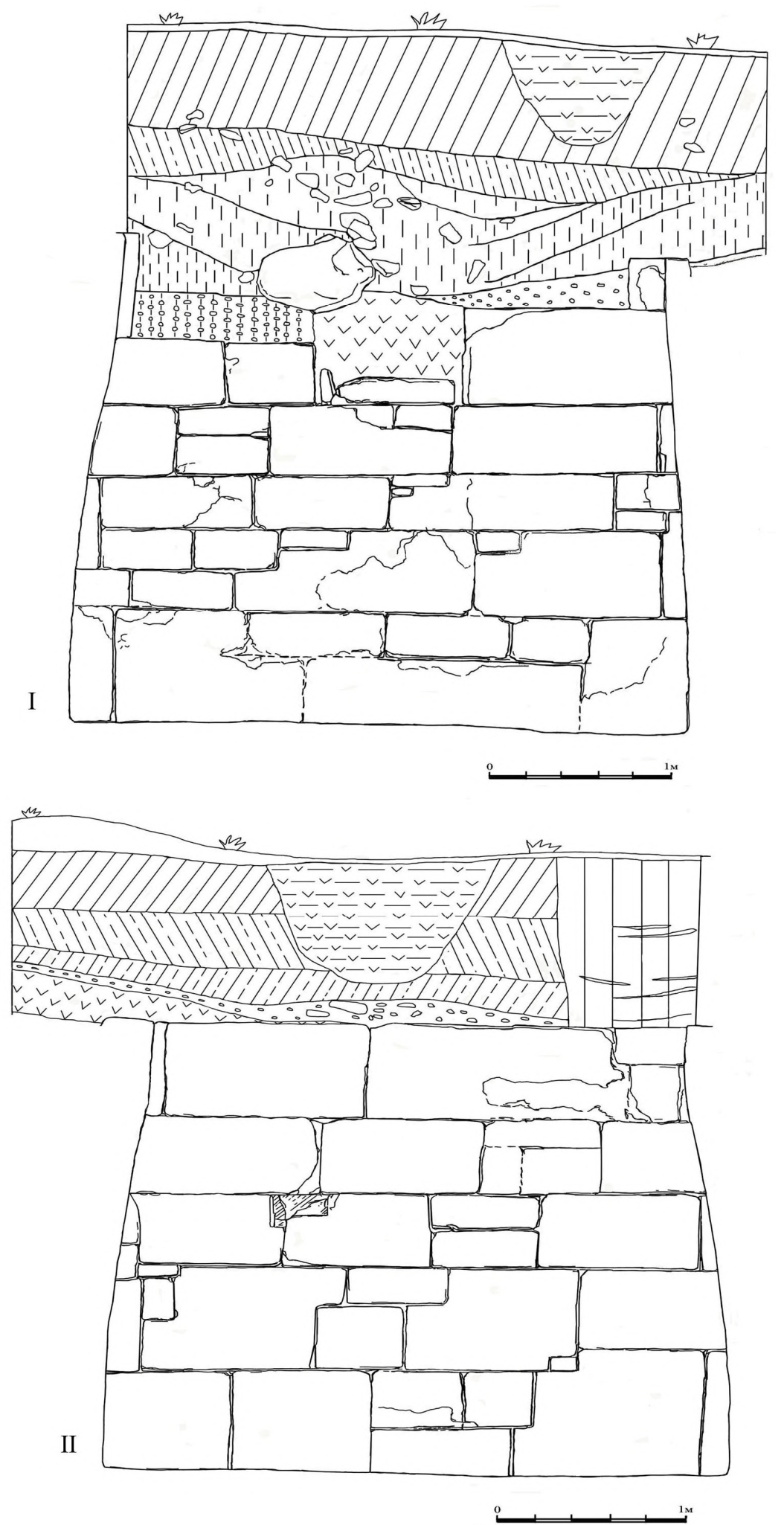

Puc. 5. Фасировка стен цистерны со стратиграфией: I - западной; II - восточной 
Описание южной стены.

Длина кладки составила, 2,7 м - в верхней части, и 3,1 м - в нижней. Стена выявлена на глубине 1,15-1,4 м, высотой 2,85-3,05 м. Кладка однолицевая и сложена в орфостатной сложной иррегулярной системе. Блоки разных размеров от 0,35х0,3 до 0,6-1,1х1,0 м, прослежено 6 рядов. Верхний ряд практически разобран, сохранилось два камня. Отдельные блоки имели уступчатую форму. Пространства в местах с уступами закладывались более мелким камнем. Возможно, при транспортировке камни были повреждены, а при установке места сколов обработаны в виде уступов. Нижний ряд состоял из более массивных блоков (0,9х0,9 м). На стенах сохранились отдельные участки штукатурки. Лучше сохранились в нижней части ближе к полу, толщиной 0,3-0,5 см. В третьем ряду в центре стены на глубине 2,3 м отсутствовал блок $(0,8 \times 0,5$ м), что образовало нишу (рис. 4, II). Возможно, она использовалась в качестве входа в склеп в позднескифское время5.

Описание западной стены.

На глубине 1,0-1,3 м, в стратиграфии, прослежены остатки кладки, возведенной в позднескифское время или несколько позже, после прекращения использования цистерны в качестве погребального сооружения. Стена находилась на глубине 1,41,9м. Часть верхних камней разобрана. В центре стены, плашмя положен камень размером 0,6х0,2х0,1 м. По всей вероятности, он использовался как порог постройки позднескифского времени. Длина западной стены была 2,95 м- сверху; 3,35 м - снизу, толщиной 0,4 м, а высотой 2,4-2,8 м. Кладка, как и у остальных стен, однолицевая. Сложена она в орфостатной сложной системе, второй и третий ряды - в иррегулярной системе. Блоки разных размеров, от 0,5х0,25 до 1,1х0,55-1,3 м. В отдельных местах стены сохранилась штукатурка, несколько лучше в нижней части (рис. 5, I).

\section{Описание восточной стены.}

Длина стены составила: в верхней части 2,8 м, а в нижней 3,3 м, высота 3,0 м, а зафиксирована на глубине 1,2 м. Кладка однолицевая, сложена в орфостатной сложной системе. Нижние три ряда построены в иррегулярной системе. Прослежено всего 5 рядов кладки. Блоки имели размеры - от 0,3х0,3 м до 1,6х0,6-0,8 м, а отдельные камни имели уступчатую форму. В кладке двух нижних рядов блоки имели бо́льшие размеры, чем в остальных рядах. На стене сверху сохранились фрагменты штукатурки размером 0,4х0,2 м. В северной части стены, на глубине 2,35 м, в 0,8 м от северовосточного угла цистерны, находилось грубо пробитое сквозное отверстие (ниша) прямоугольной формы размером 0,3х0,15 м. Ниша создана, скорее всего, в период функционирования цистерны (рис. 5, II). Предположительно, это мог быть канал (трубопровод?) для поступления воды в цистерну из других емкостей. Первоначально предполагалось, что это могла быть ниша для светильника6

\section{Материал из заполнения цистерны.}

Заполнение цистерны состояло из линз глины (сырца), перемешанной с черноземом и содержало крупные блоки известняка и мелкие фрагменты от каменной конструкции. Размеры блоков $(1,0 x 0,6 \times 0,5$ м) и грубый характер их обработки, отличающийся от кладок цистерны, позволяют предположить, что они происходят не из кладок цистерны. Несколько прямоугольных блоков размером 1,3х0,3х0,3м, видимо, происходили из разобранных внешних стен усадьбы и зафиксированы в стратиграфическом разрезе (рис. 6, I).

\footnotetext{
5 Пуздровский А.Е., Медведев Г.В., Соломоненко А.Е., Труфанов А.А. Охранные исследования Альминской экспедиции в 2008 г. // Археологічні дослідження в Україні 2008. Київ, 2009. С. 249. 6 Ibidem.
} 

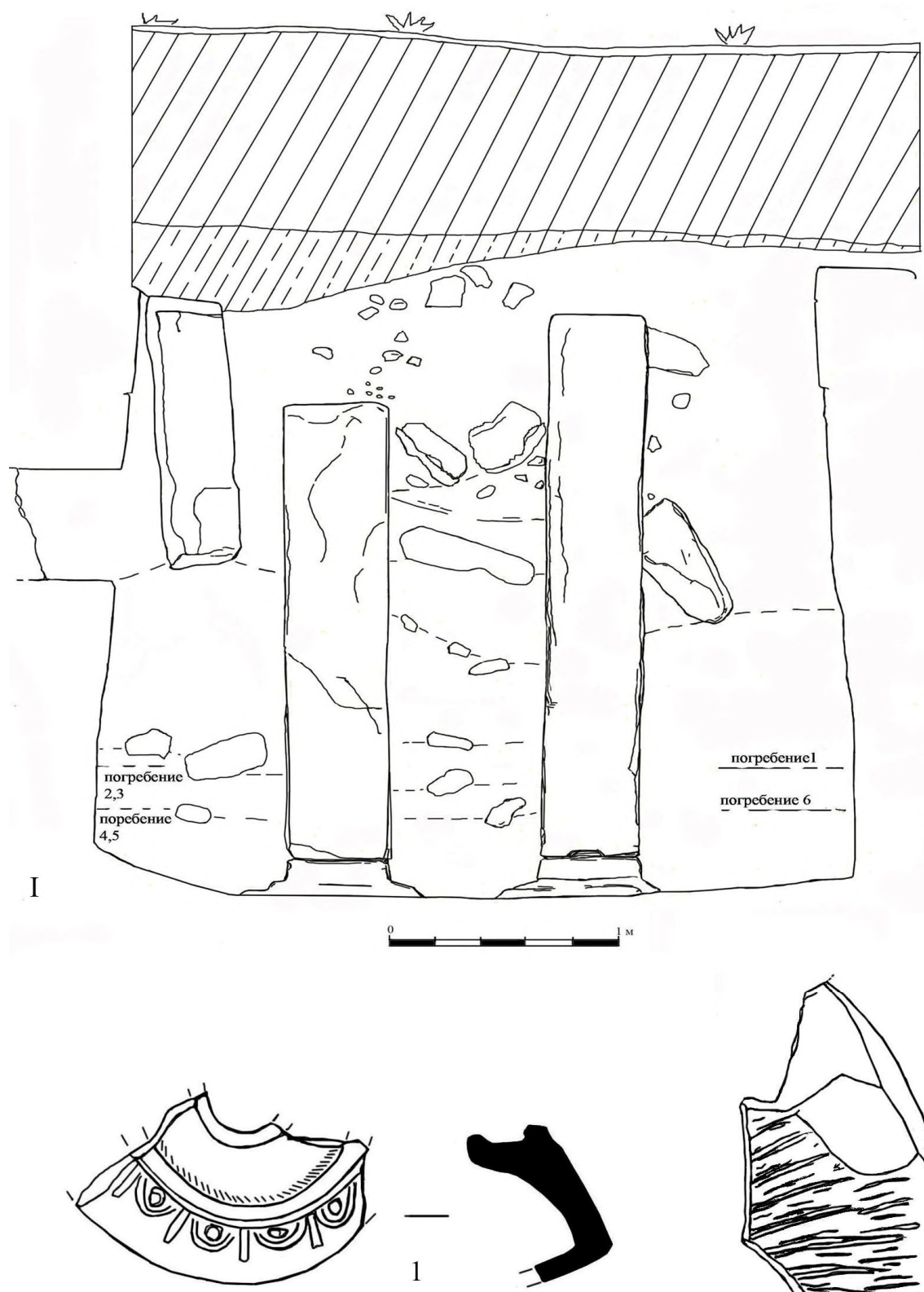

II

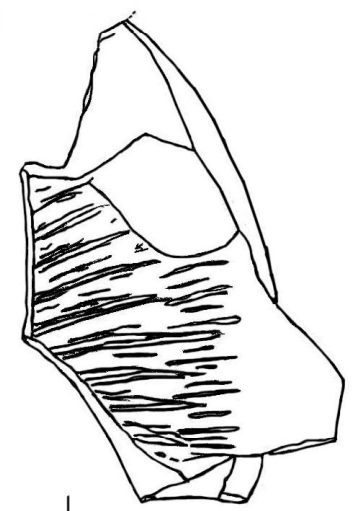

2
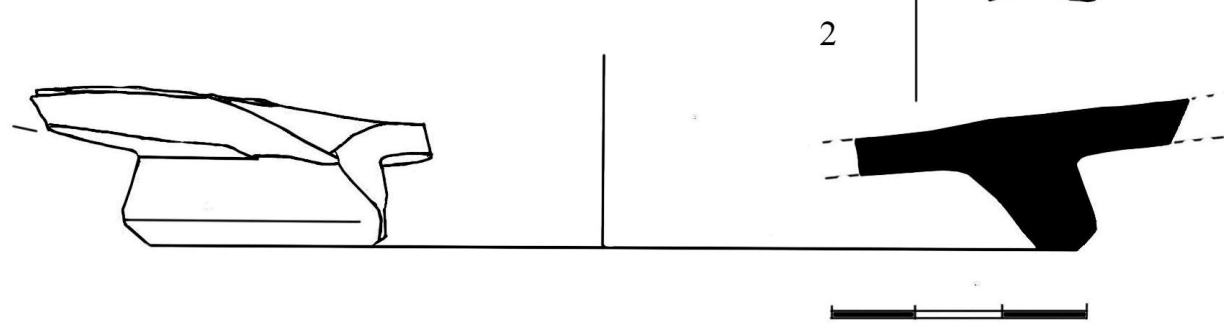

Puc. 6. I - Разрез по линии север-юг со стратиграфией заполнения цистерны; II - Фрагменты профильных частей чернолаковой посуды: 1 - светильника; 2 - тарелки 

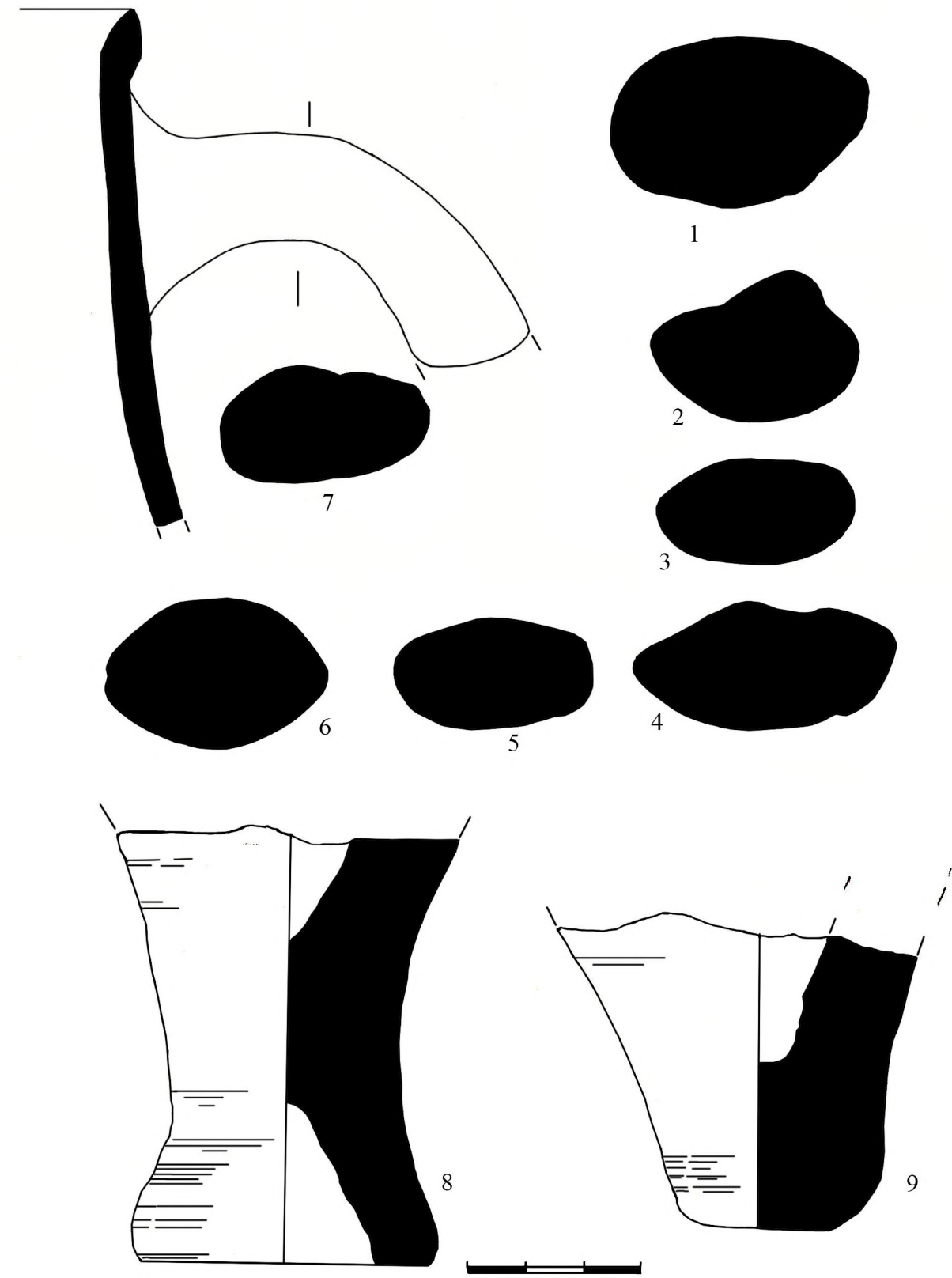

Рис. 7. Фрагменты профильных частей амфор:

1, 4 -красноглинянные; 2- светлоглинянные; 3, 5-9 - Синопа

Слой заполнения цистерны насыщен фрагментами гончарной керамики, амфорной тары и черепицы. В нижней части заполнения в большом количестве попадались разрозненные, раздробленные человеческие кости и остатки инвентаря погребений: краснолаковой и лепной посуды, бронзовых браслетов, гривн, бус из стекла, фаянса, сердолика и гагата и др.

Черепица. В заполнении цистерны зафиксированы обломки кровельной черепицы, которая представлена двумя центрами - Синопой и Херсонесом, которые составили $3,2 \%$ от общего количества керамики (табл. 1). 

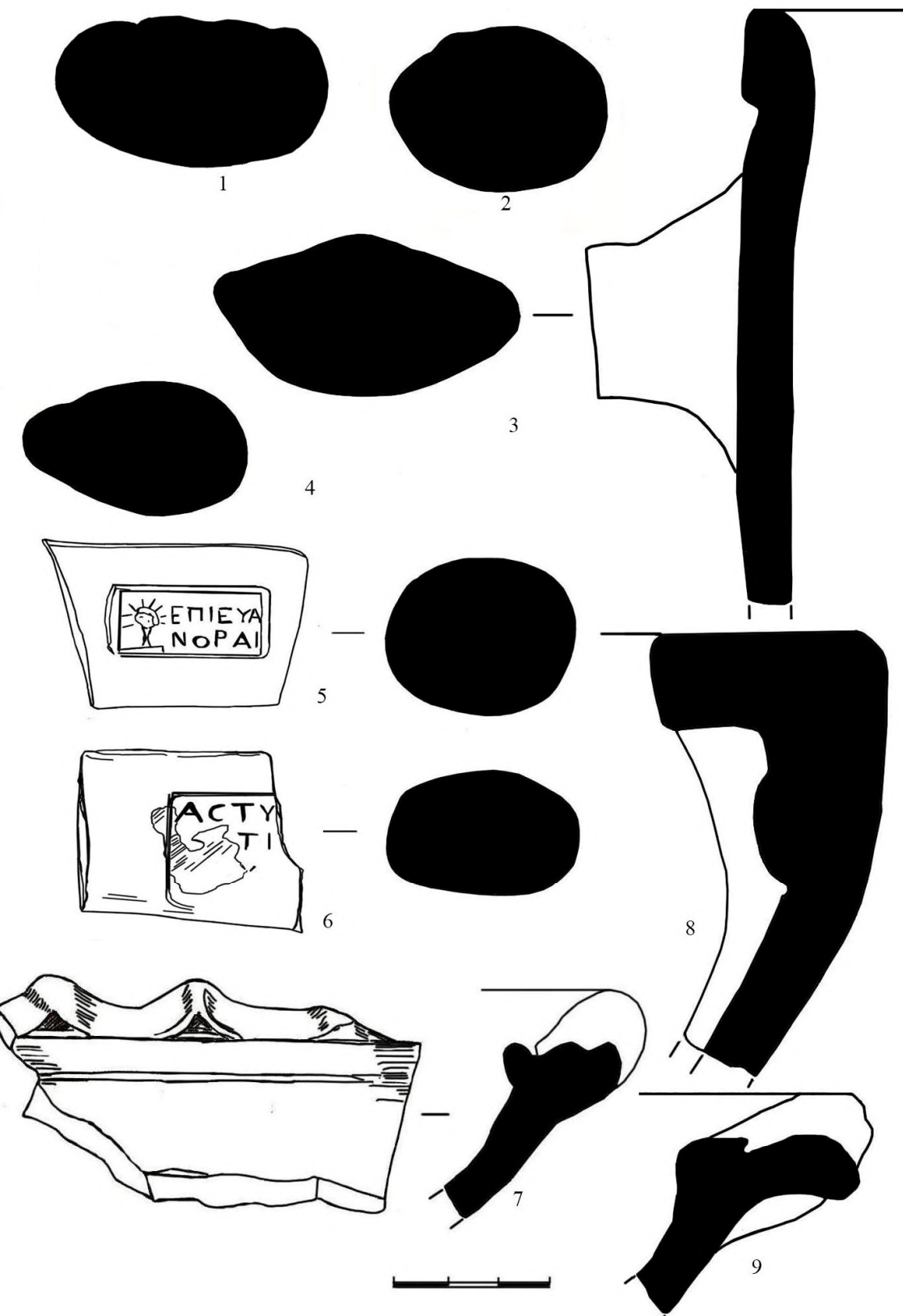

Pис. 8. Фрагменты профильных частей амфор и кухонной посуды:

1, 6 - Синопа; 2, 4 - красноглиняные; 5 - Родос; 3, 7-9 - Херсонес

Амфоры. Общее количество фрагментов амфорной тары составило $2 / 3$ от общего количества керамики. Наибольшее количество фрагментов амфорной тары - от херсонесских амфор 39,6\% (табл. 2). Среди обломков тары удалось по профильным частям определить некоторые типы херсонесских амфор: это типы I, IIB и III (рис. 7, 3, 7, 8; 10, 4; 11, 1, 9-11; 12, 7)7. Несколько меньшее число найдено фрагментов

\footnotetext{
7 Монахов С.Ю. Амфоры Херсонеса Таврического IV-II вв. до н.э. Опыт системного анализа: монография. Саратов: Издательство Саратовского университета, 1989. С. 42-59, 62-64, 140, таб. XIV, XVIII, XX.
} 
синопских амфор 31,9\% (табл. 2). Среди них определены типы IIIC и IIID (рис. 7, 5, 9; $9,5 ; 10,1,2 ; 11,2,6,7,8,11 ; 12,6,8,9,10)^{8}$. Среди осколков синопских амфор, обнаружен фрагмент ручки с частью астиномного клейма**** попавшего, скорее всего, при засыпке цистерны (рис. 8, 6):

$$
\begin{aligned}
& \text { [E } \Sigma \text { ]TI[AIOY] } \\
& \text { [KАEANETOY] }
\end{aligned}
$$

\section{Канфар}

астином Гестиэй 1 (V MГ, подгруппа A)99. В заполнении цистерны обнаружены единичные фрагменты родосских амфор типов IIA-1 или 2A-6 (по типологии А.П. Абрамова), 1-Е-2 (по типологии С.Ю. Монахова) (рис. 9, 2; 11, 5, 13)10.

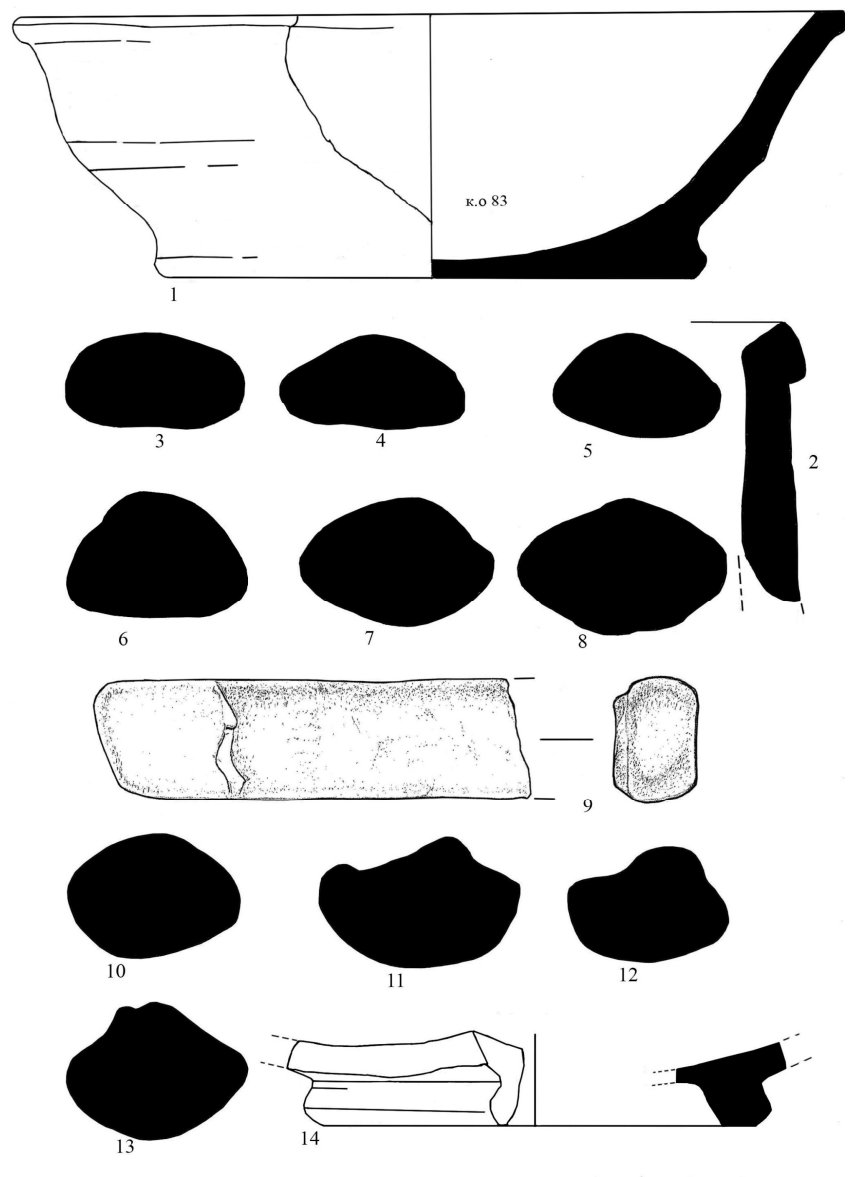

Puc. 9. Фрагменты профильных частей гончарной посуды и амфор: 1, 3, 5, 14 - Синопа; 4, 6 - Херсонес; 10 - Книд; 7, 8, 11-13 - светлоглиняные узкогорлые; 9 - точильный камень

\footnotetext{
8 Монахов С.Ю. Греческие амфоры в Причерноморье. Типология амфор ведущих центровэкспортеров в керамической таре: каталог-определитель. Москва, Саратов: Киммерида, 2003. С. 153-155, табл. 104, 105, 1-4.

**** Выражаю благодарность А.А. Гаврилову за помощь в определении клейм.

9 Граков Б.Н. Древнегреческие керамические клейма с именами астиномов: монография. Москва: РАНИОН, 1928. табл. 6; 7; Кац В.И. Греческие керамические клейма эпохи классики эллинизма (опыт комплексного изучения) // Боспорские исследования. 2007. Вып. 18. С. 435.

${ }_{10}$ Абрамов А.П. Античные амфоры. Периодизация и хронология // Боспорский сборник. Вып. 3. Москва, 1993. С. 42, рис. 43, 4.10; Монахов С.Ю. Греческие амфоры в Причерноморье... С. 118.
} 

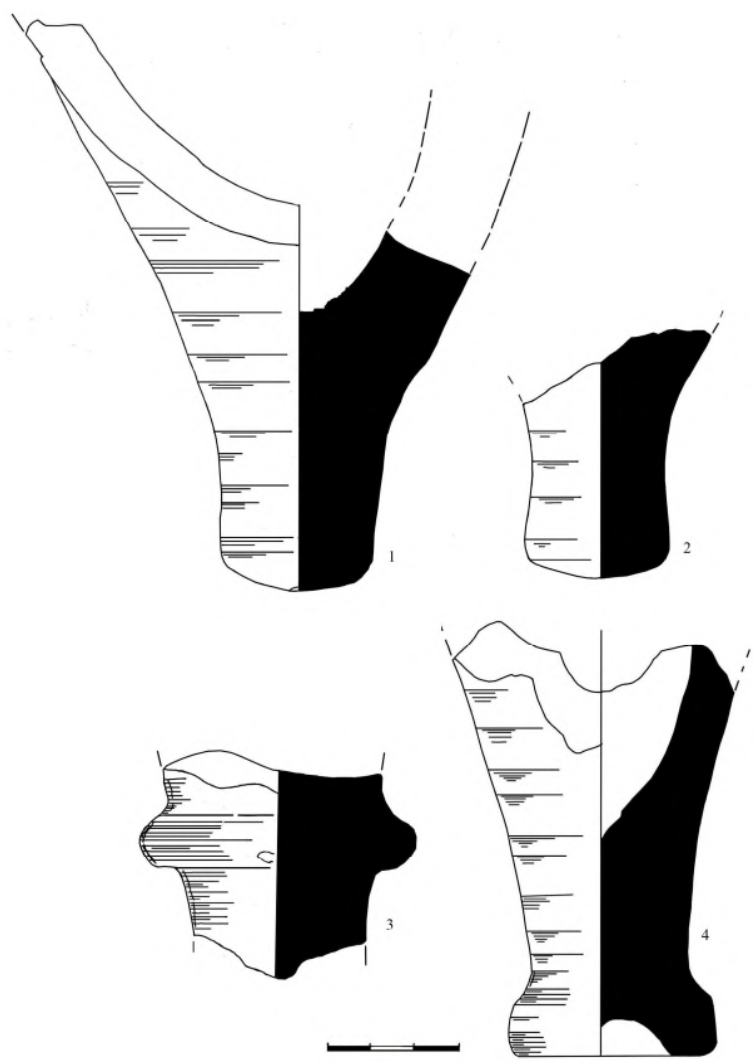

Pис. 10. Фрагменты ножек эллинистических амфор:1, 2 - Синопа; 3 - Книд; 4 - Херсонес.

Среди прочей амфорной тары, найдены фрагменты книдских амфор. Встречается тип IIF или IIG по типологии (С.Ю. Монахова) (рис. 10, 3) ${ }^{11}$. Здесь же имеются единичные фрагменты амфор с двуствольным ручками ${ }^{12}$. Небольшое количество фрагментов светлоглиняных амфор (рис. 9, 11, 12). Керамическая тара рубежа н. э. и первых веков н.э. представлена обломками красноглиняных амфор (рис. 7, 1; 8,2; 12, 4). А кроме этого, фрагментами светлоглиняных узкогорлых амфор типов А и С по типологии Д.Б. Шелова и встречаются с конца I в. до н.э. - по I в. н.э. и во II в. н.э. (рис. 11, 3; 9, 13, табл. 3) ${ }^{13}$. По мнению А.П. Абрамова, тип А относится - к концу І в. до н.э. - середине Ів. н.э.; а тип C - к концу Iв. н.э. - началу II в. н.э ${ }^{14}$. По классификации С.Ю. Внукова это типы C-IVA1 (вторая - начало последней четверти I в. н.э.) и C-IVA2 (60-е гг. - конец I в. н.э.), а также тип C-IVC (вторая четверть - конец II в. н.э.) ${ }^{15}$. Среди фрагментов амфор найдена ножка амфоры рюмковидной формы (рис. 11, 14).

\footnotetext{
11 Монахов С.Ю. Греческие амфоры в Причерноморье... С. 109.

12 Абрамов А.П. Античные амфоры... С. 44-45, рис. 48.

13 Шелов Д.Б. Узкогорлые светлоглиняные амфоры первых веков нашей эры. Классификация и хронология // Краткие сообщения института археологии. 1978. Вып. 156. С. 17-18.

${ }^{14}$ Абрамов А.П. Античные амфоры... С. 45-46.

15 Внуков С.Ю. Причерноморские амфоры І в. до н.э. - II в. н.э. (морфология): монография. Москва: Институт археологии Российской академии наук, 2003. Рис. 45; Внуков С.Ю. Причерноморские амфоры. І в до н.э. - II в. н.э. Петрография, хронология, проблемы торговли: монография. СанктПетербург: Алетейя, 2006. С. 167.
} 

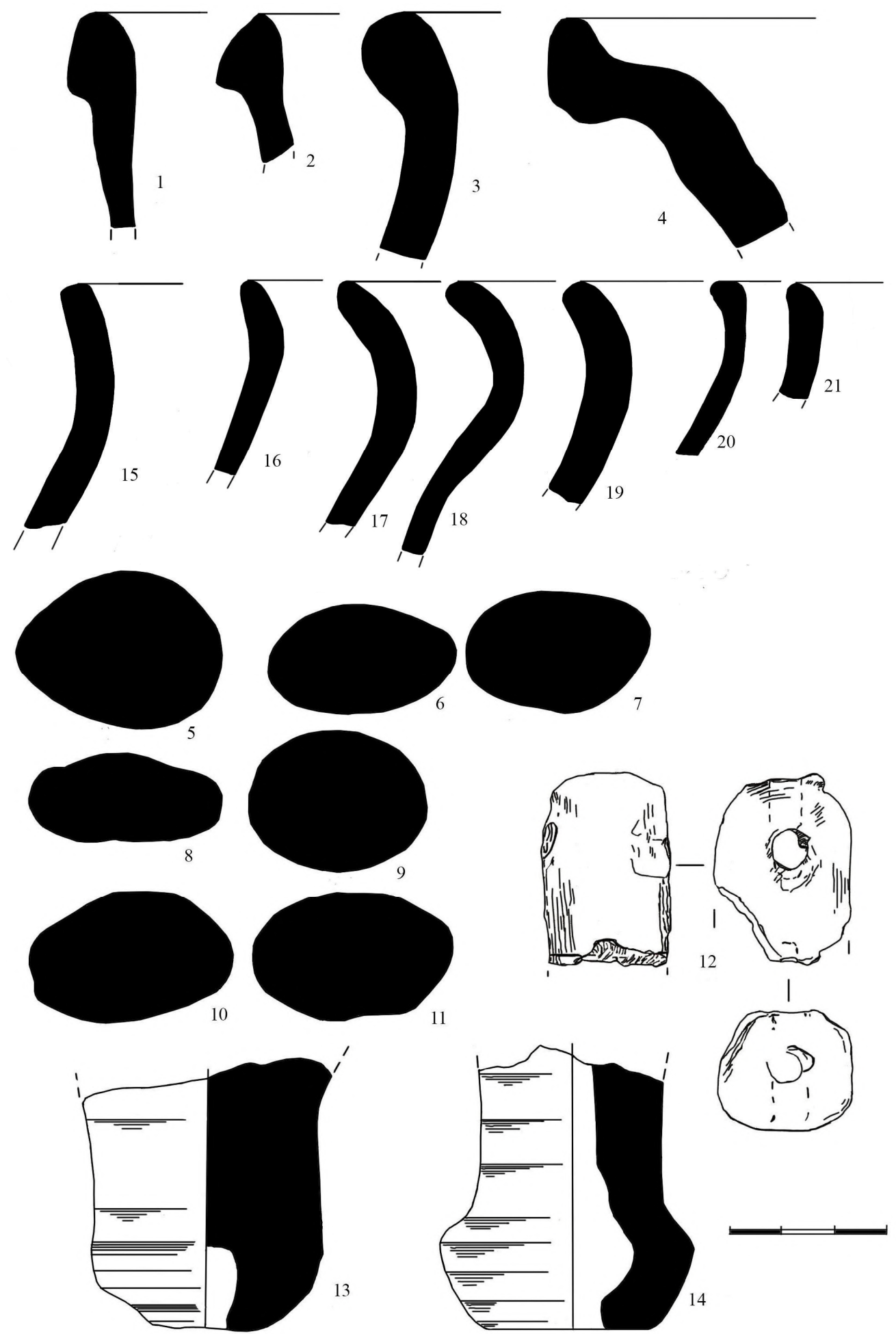

Puc. 11. Фрагменты профильных частей амфор, гончарной, лепной посуды: 1, 4, 9, 10 - Херсонес; 3 - светлоглиняные узкогорлые; 2, 5-8, 11, 13 - Родос; 14 - с рюмковидной ножкой; 15-21 - лепной посуды; 12 - лепного грузила. 

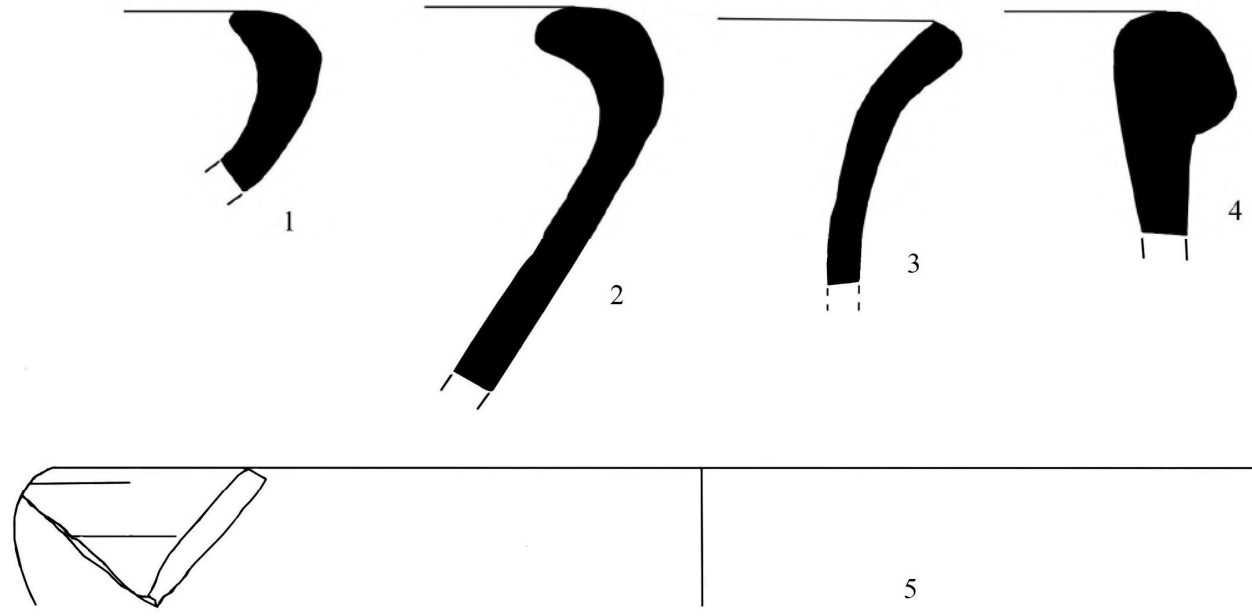

5

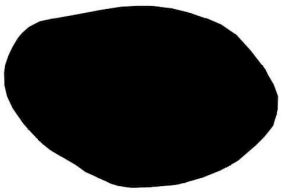

6
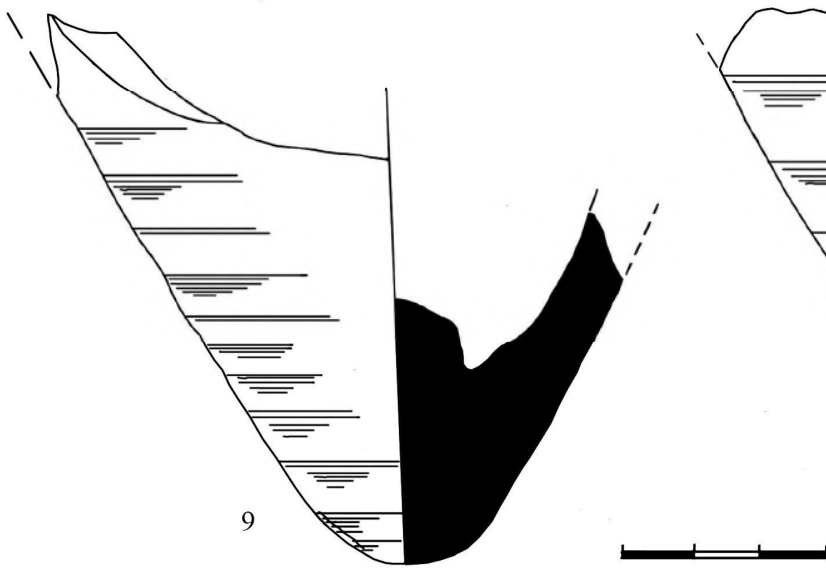
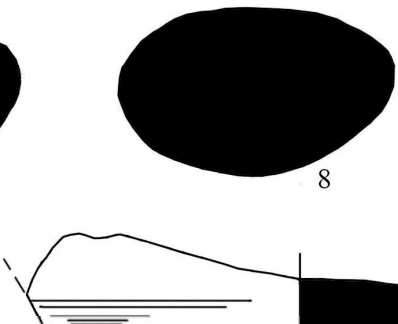

Рис. 12. Фрагменты профильных частей гончарной, лепной посуды, и амфор: 1, 2, 7 - Херсонес; 3 - лепной; 4 - красноглиняной; 5 - краснолаковой тарелки; 6, 8-10 - Синопа

В заполнении выявлены фрагменты амфорной тары различных центров, которые используют от последней трети IV - до I-II вв. н.э (табл. 3). Большинство амфорной тары происходит из Херсонеса, остальные происходят из Причерноморских (Синопа) и Средиземноморских античных центров (Родос, Книд и др.).

Гончарная керамика представлена профильными частями и стенками столовой (рис. $13,8-11 ; 14,4$ ) и кухонной посуды, в основном, синопского и херсонесского производства 9,6\% (табл. 1). Среди прочих, в заполнении обнаружен профиль синопской гончарной красноглиняной миски с отогнутым венчиком на плоском поддоне (рис. 9, 1). Похожая посуда встречается на Боспоре. Многие формы красноглиняной, 
повторяются среди сероглиняной керамики ${ }^{16}$. В слое найдены обломки венчиков лутериев и пифоса херсонесского производства (рис. 8, 7, 9; 11, 4). Столовая и кухонная посуда эллинистического и римского времени встречается в Херсонесе и на его хоре, а также в других античных городах Крыма17. Среди обломков гончарной керамики обнаружены фрагменты дна чернолаковой тарелки с концентрическими насечками аттического производства (рис. 6, II, 2). Подобные тарелки известны в Северо-Западном Крыму и других городах Причерноморья в IV-II вв. до н.э. ${ }^{18}$

Лепной посуды зафиксировано небольшое количество фрагментов (около 9,6\%) - это профильные части и стенки горшков и кувшинов (табл. 1). На городище в эллинистический период встречается до $30 \%$ лепной керамики от всей керамики ${ }^{19}$. Среди фрагментов лепной посуды интересен фрагмент венчика сосуда с пальцевыми вдавлениями по валику на горле (рис. 13, 7). Подобная лепная керамика встречается на скифских поселениях и характерна для IV-II вв. до н.э., но в незначительном количестве известна и в позднескифское время ${ }^{20}$.

В грабительском отвале найден фрагмент сероглиняного светильника с чернолаковым покрытием и рельефным орнаментом в виде ов эфесского производства. Такие светильники встречаются в комплексах, начиная с III в. до н.э. - по I в. н.э. ${ }^{21}$ Отсюда же происходит фрагмент ручки родосской амфоры с эпонимным клеймом, с эмблемой в виде головы Гелиоса на подставке вправо и легендой (рис. 8,5): ЕПІ EYANOPAI. Магистрат Еванор (V XГ, подгруппа Vc), датируют временем около 119 г. до н.э. ${ }^{22}$ Данное клеймо, скорее всего, связано со слоем погребений.

В целом амфорная тара, гончарная и чернолаковая керамика эллинистического

16 Буйских С.Б. Серая гончарная керамика Боспора (попытка осмысления на фоне Северного Причерноморья) // Боспорские исследования. 2012. Вып. 26. Рис. 1,17; Данильченко С.А. Столовая керамика из раскопок Нимфея (2008-2012) // Боспорский феномен. Греки и варвары на Евразийсом перекрестке. Материалы международной конференции. Санкт-Петербург. 2013. С. 165.

17 Ушаков С.В. Керамический комплекс Херсонеса Таврического (по материалам работ BSP- Причерноморского проекта у «Базилики 1935 г.») // Материалы по археологии и истории античного и средневекового Крыма. 2010. Вып. II. Рис. 5, 7-13, 17, 19; Буйских С.Б. Указ. раб. Рис. 8, 2; Егорова Т.В. Новая раннеэллинистическая усадьба на городище «Чайка» и ее место в структуре поселения // Stratum plus. 2014. № 3. Рис. 21, 1-4, 7; Гаврилов А.В. Округа античной Феодосии: монография. Симферополь: Азбука, 2004. С. 93, рис. 88, 57; 99, 16.

18 Егорова T.Н. Чернолаковая керамика IV-II вв. до н.э. с памятников Северо-Западного Крыма: монография. Москва: Московский государственный университет, 2009. Рис. 27; 28; Егорова Т.Н. Чернолаковая керамика V-IV вв. до н.э. с прочерченным штампованным орнаментом из раскопок Пантикапея // «С Митридата дует ветер». Боспор и Причерноморье в античности. К 70-тилетию В.П. Толстикова / О.Л. Габелко (отв. ред.). Москва: Университет Дмитрия Пожарского, 2015. Рис. 6, 1-3.

19 Колтухов С.Г., Зубар В.М., Миц В.Л. Вказ. пр. С. 90.

20 Мелюкова А.И. Памятники скифского времени лесостепного Среднего Поднестровья // Материалы института археологии. 1958. Вып. 64. Рис. 30; Погребова Н.Н. Позднеские городища на Днепре (Городище Знаменское и Гавриловское) // Материалы института археологии. 1958. Вып. 64. Рис. 42; Высотская Т.Н. Неаполь - столица государства поздних скифов. Киев: Наукова думка, 1979. Рис. 37, 1, 2.

${ }_{21}$ Шейко И.Н. Пергамские и Эфесские светильники из Ольвии. (импорт и местные имитации) // Проблемы истории, филологии, культуры. Москва, Магнитогорск, Новосибирск: Магнитогорский государственный технический университет. 2014. Вып. 2. С. 116. Рис. 6, 7; Шейко И.Н. Світильники Ольвії (кінець VII-I ст. до н.е.). Дис... канд. ист. наук. Київ, 2015. С. 120, рис. 136, 5; Журавлев Д.В., Турова Н.П. Античные глиняные светильники Ялтинского историко-литературного музея // Боспорские исследования. 2012. Вып. 26. Табл. 4, 22.

22 Finkielsztejn G. Chronologie detaillee et revise des eponymes amphoriqes rhodiens. de 270 a 108 av, J.C. environ. Preier bilan. Bar International Series 990. 2001. Р. 195; Кац В.И. Указ. раб. С. 421. 
времени, свидетельствуют о широких торговых контактах поселения не только с Херсонесом, но и другими Причерноморскими Средиземноморскими античными центрами (Синопа, Родос, Аттика, Книд, Эфес и др.).
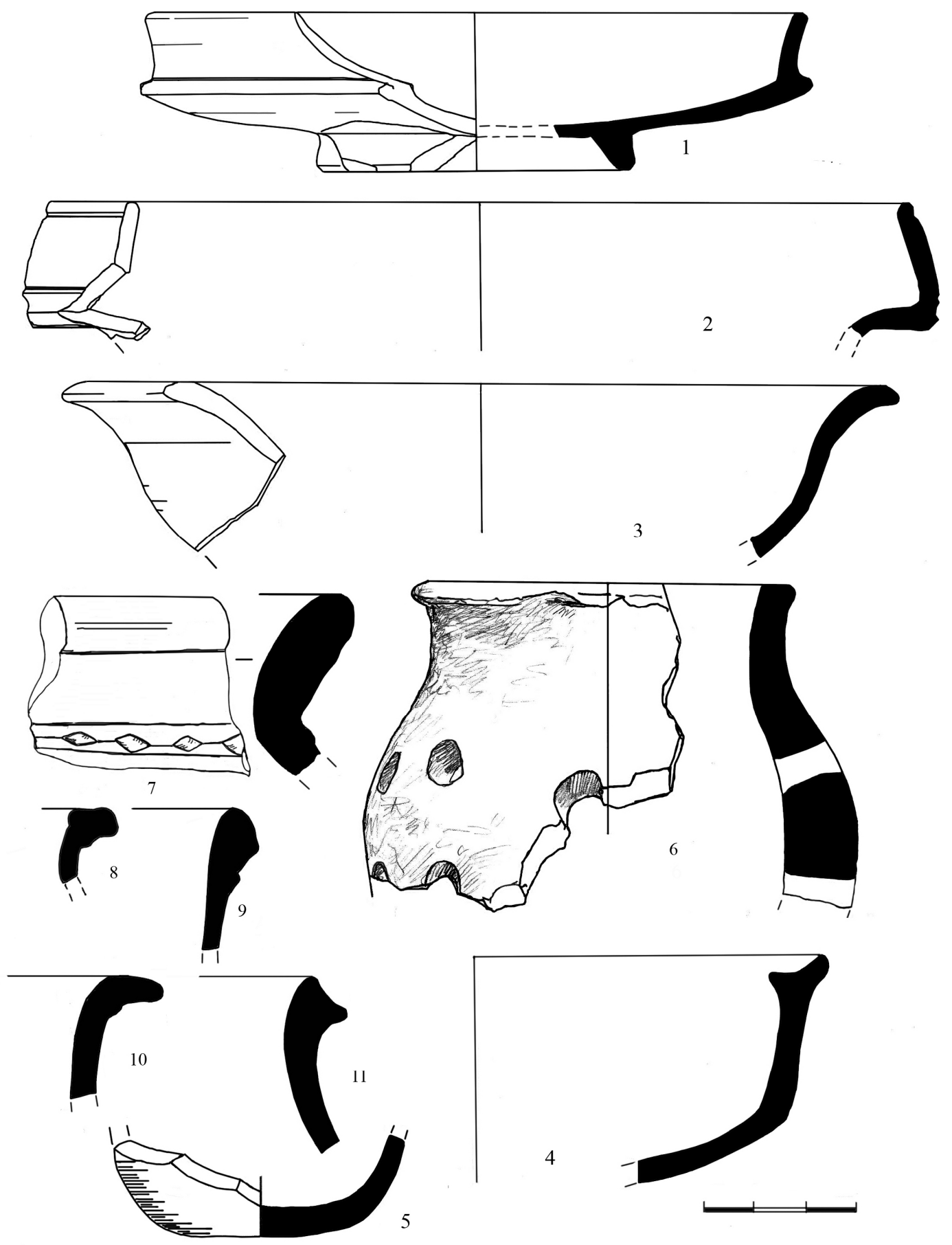

Puc. 13. Фрагменты краснолаковой, гончарной и лепной посуды из слоя погребений: 1-4 - краснолаковой; 5 - гончарного флакона; 6, 7 - лепной; 8-11 - гончарных сосудов 
Горизонт погребений зафиксирован на глубине 3,4-3,9 м от уровня современной дневной поверхности. Он представлен значительным количеством костных остатков.

После подсчета костей определено, что в склепе было погребено не менее 30 человек. Практически все костные останки находились в разрушенном состоянии, и фрагменты раздробленных костей фиксировались на разной глубине с остатками фрагментированного погребального инвентаря.

Инвентарь погребений.

В заполнении цистерны, из разрушенных погребений происходят обломки краснолаковой посуды:

1. Канфара типа 2 - по типологии А.А. Труфанова (рис. 14,1$)^{23}$.

2. Чашки с налепами типа 2, 1 варианта (по А.А. Труфанову) (рис. 13, 2; 14, 2, 5)24.

3. Миски формы 16, 3 по типологии Д.В. Журавлева (рис. 14, 3) 25.

4. Тарелок фрагменты PS (Pontic sigillata) (по А.А. Труфанову) (рис. 12, 5; 13, 3)26.

5. Тарелки типа 3-E-3 (по А.А. Труфанову) (рис. 13, 1)27.

6. Тарелки типа II (по А.А. Труфанову) (рис. 13, 4) 28.

Краснолаковая керамика из цистерны датируется периодом от середины I в. н.э. - до конца II в. н.э. (табл. 4). Единственное то, что дата распространения тарелки типа II выходит за пределы II в. н.э.

В слое погребений обнаружены, фрагменты горла и дна стеклянного и гончарных бальзамариев (рис. 16,13; 13,5). Аналогичные сосуды встречаются в позднескифских погребениях со второй половины I - до середины III в. нэ., а также в середине - второй половине I в. н.э. Они известны в погребениях Усть-Альминского и Битакского некрополей 29.

В слое, среди костей, найдены три лепных пряслица (рис. 16, 10-12), астрагал и фрагмент морской раковины (рис. 15, 9, 10).

Из лепной посуды найдены фрагменты неорнаментированной курильницы в форме горшочка с раздутым туловом и отверстиями в стенках (рис. 16, 6). Такие курильницы встречались в позднескифских погребениях Беляусского некрополя и Неапольского городища и некрополя. Они распространены во II-I вв. до н.э, а иногда встречались в первые века н.э. ${ }^{30}$

23 Труфанов А.А. Хронология могильников Предгорного Крыма I в. до н.э. - III в н.э. // Stratum Plus. 2009. Вып. 4. С. 160, рис. 22, 3-5.

24 Ibid. С. 154, pис. 19, 4-7.

25 Журавлев Д.В. Понтийская сигиллата из могильников Бельбек III и Бельбек IV в Юго-Западном Крыму // Боспорские исследования. 2007. Вып. 16. С. 376, рис. 5.

26 Труфанов А.А. Хронология могильников Предгорного Крыма... С. 153, рис. 15, 2; 18, 8.

27 Труфанов А.А. Типология краснолаковых тарелок с вертикальным бортиком (по материалам могильников Юго-Западного и Центрального Крыма) // Бахчисарайский историкоархеологический сборник. 1997. Вып. 1. С. 189-191.

28 Труфанов А.А. Хронология могильников Предгорного Крыма... С. 153, рис. 17, 1, 4.

29 Пуздровский А.Е. Крымская Скифия. II в.до н.э. - II в. н.э. Погребальные памятники: монография. Симферополь: Бизнес-Информ, 2007. Рис. 191; 192; 164, 7, 8.

30 Высотская Т.Н. Неаполь... Рис. 42; Сымонович Э.А. Население столицы позднескифского царства (по материалам Восточного некрополя Неаполя скифского): монография. Киев: Наукова думка, 1983. Табл. IV, 2; Дашевская О.Д. О скифских курильницах // Советская археология. 1980. № 1. Рис. 5, 2, 3; 6, 3, 4; Дашевская 0.Д. Поздние скифы в Крыму. Москва: Наука, 1991 (Свод археологических источников. Вып. Д1-7). Табл. 47, 2, 4; Синика В.С., Менишикова В.А., Тельнов Н.П. Лепные курильницы из памятников Северного Причерноморья в IV-І вв. до н.э. // Stratum plus. 2014. № 3. С. 77 , рис. $11,9,11,12$. 

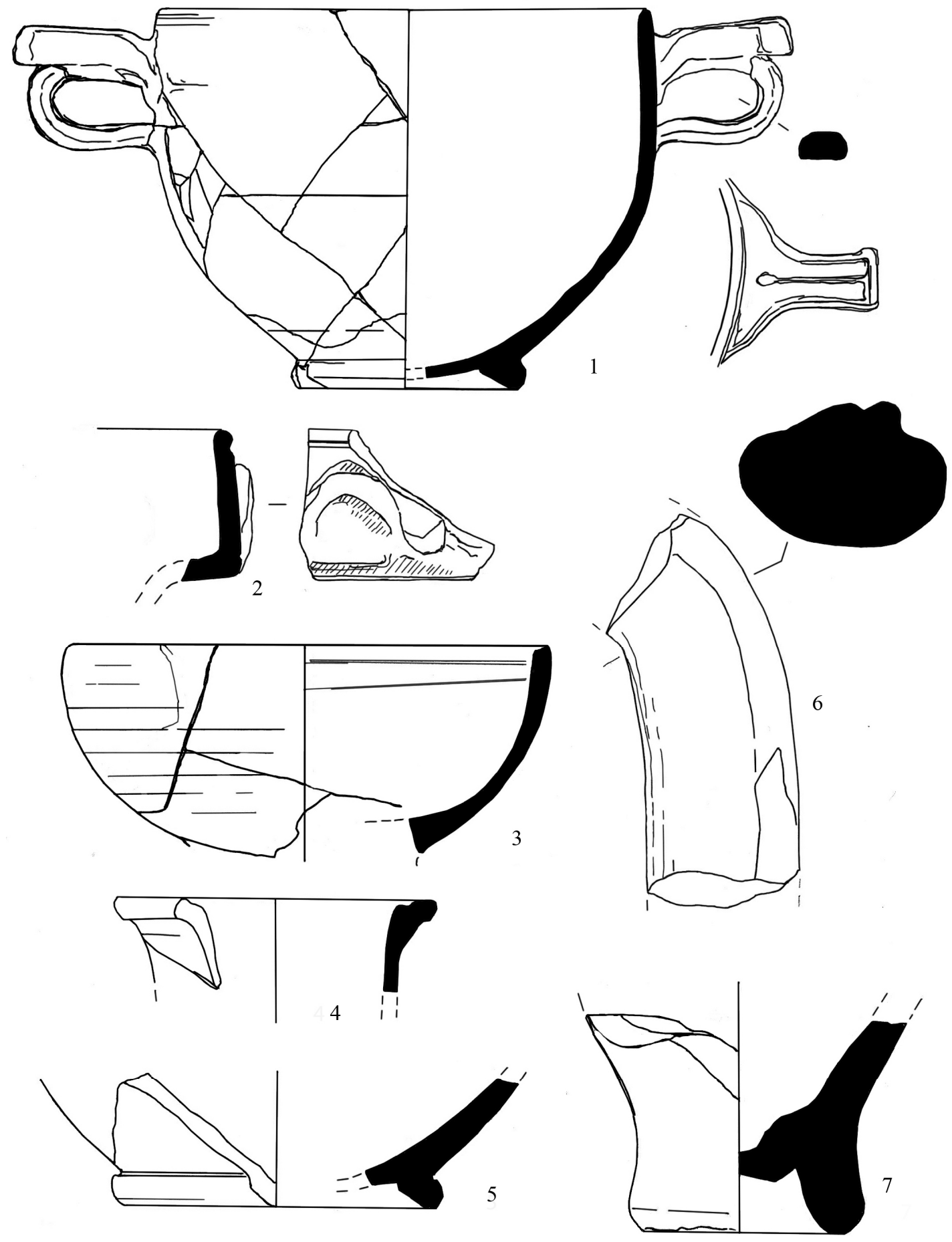

Puc. 14. Фрагменты краснолаковой посуды и амфор из слоя погребений: 1-3, 5 - краснолаковая; 4 - гончарного ; 6, 7 - светлоглинянных узкогорлых амфор 

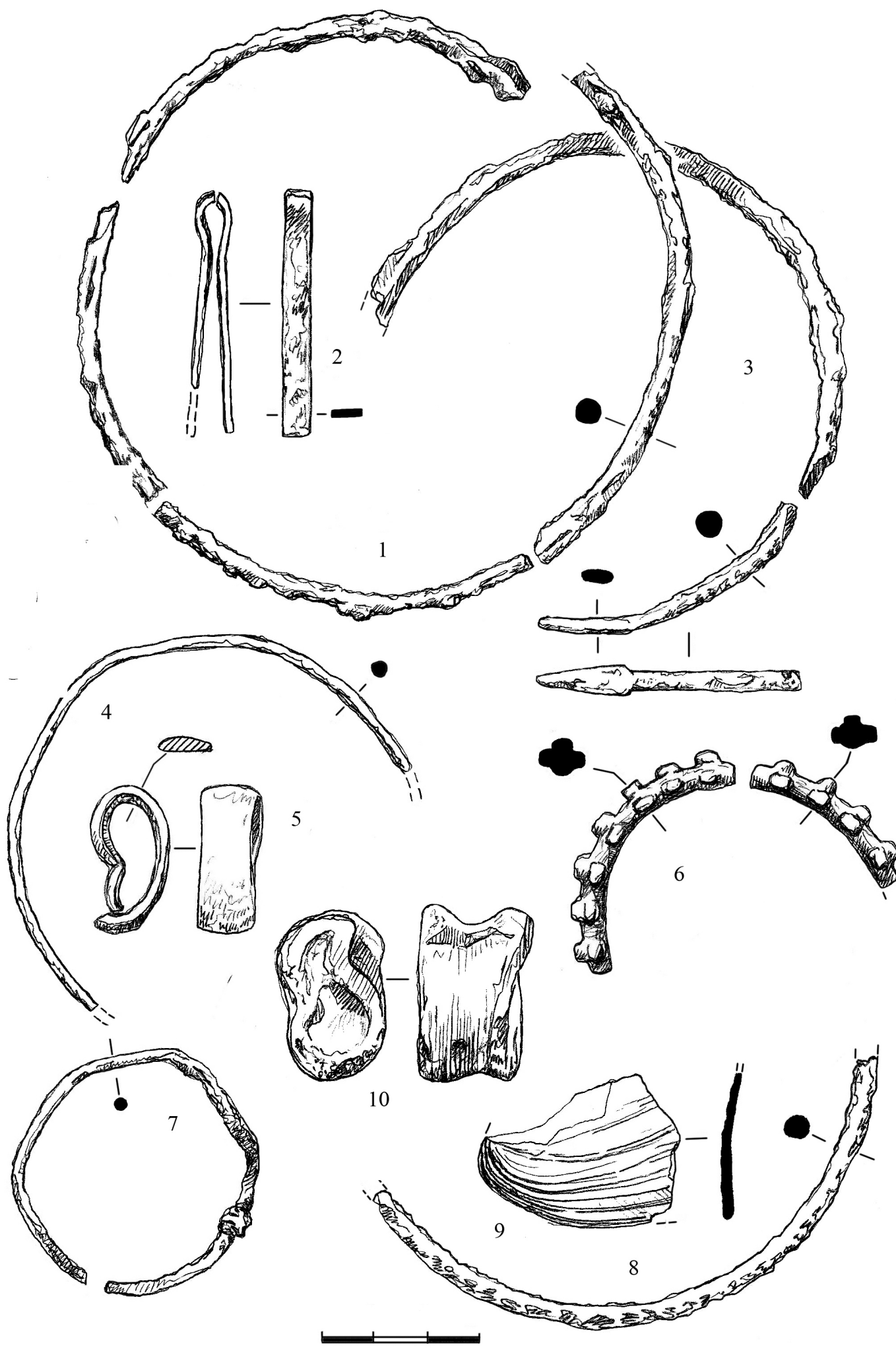

Рис. 15. Инвентарь из слоя погребений: 1-8 -изделия из бронзы; 9 - раковины, 10 - астрагал 

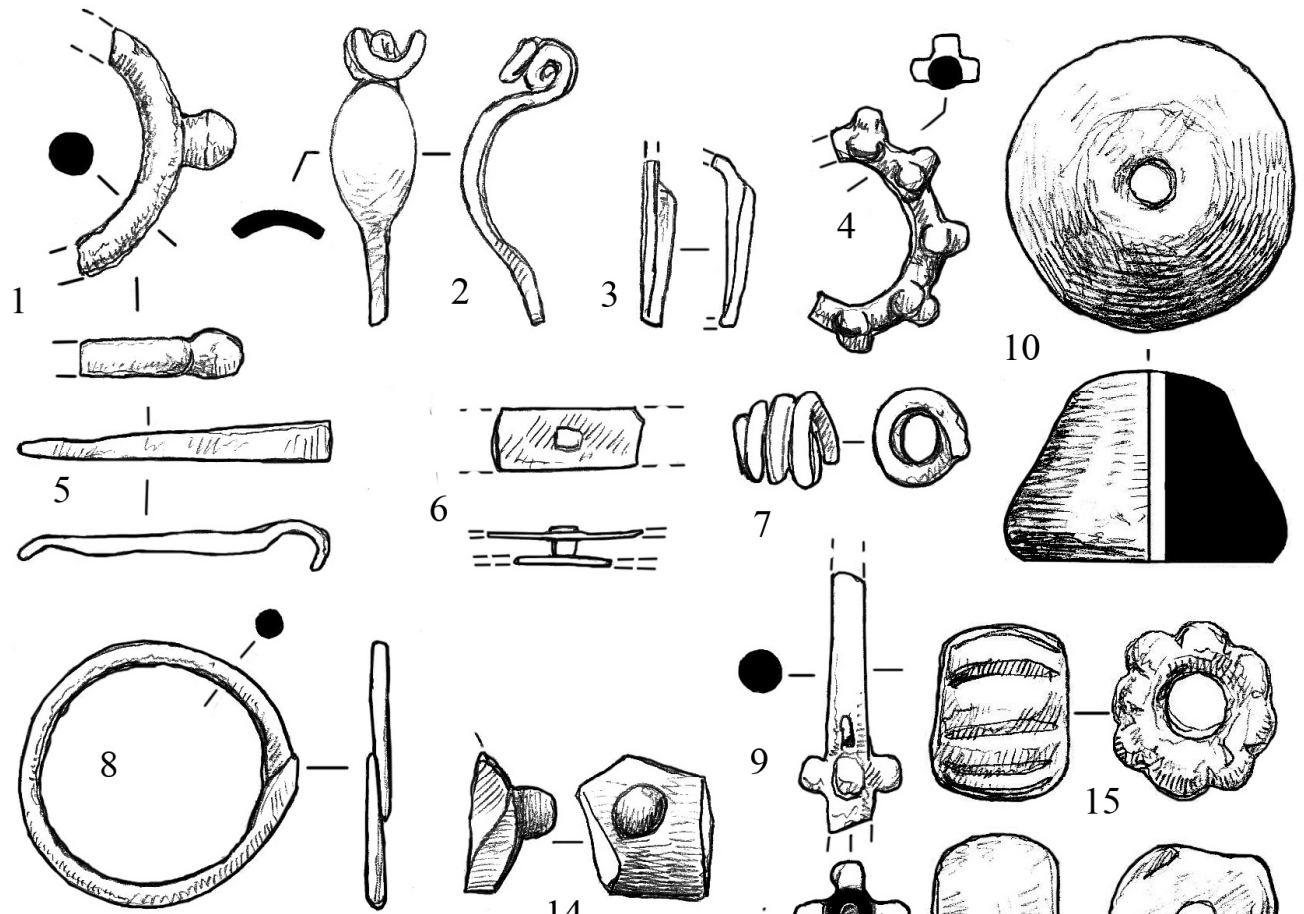

6

14
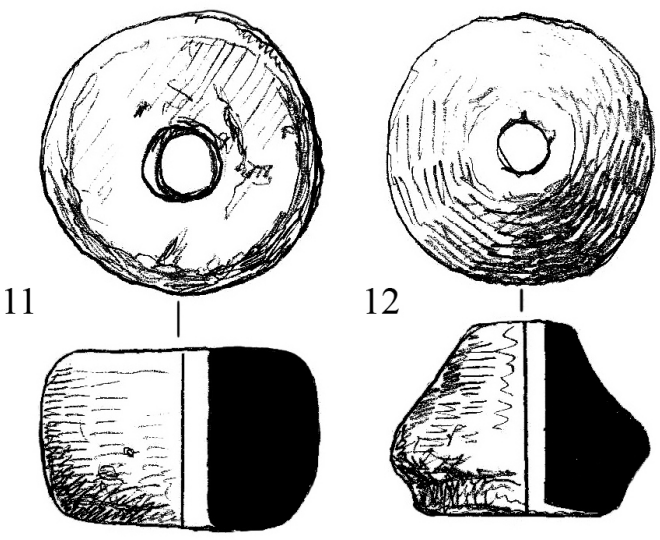

12
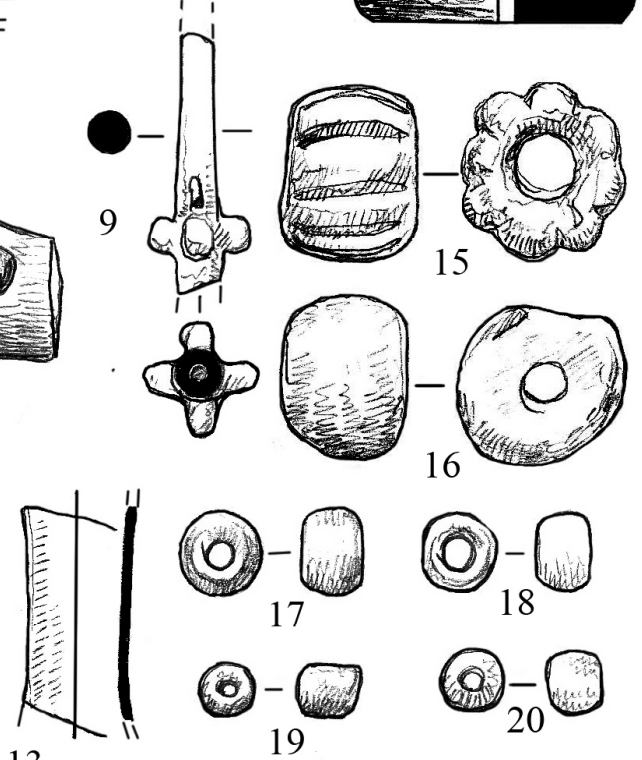

13

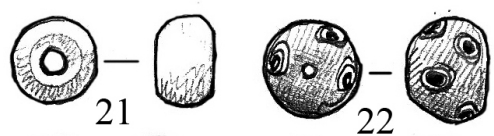
21

22
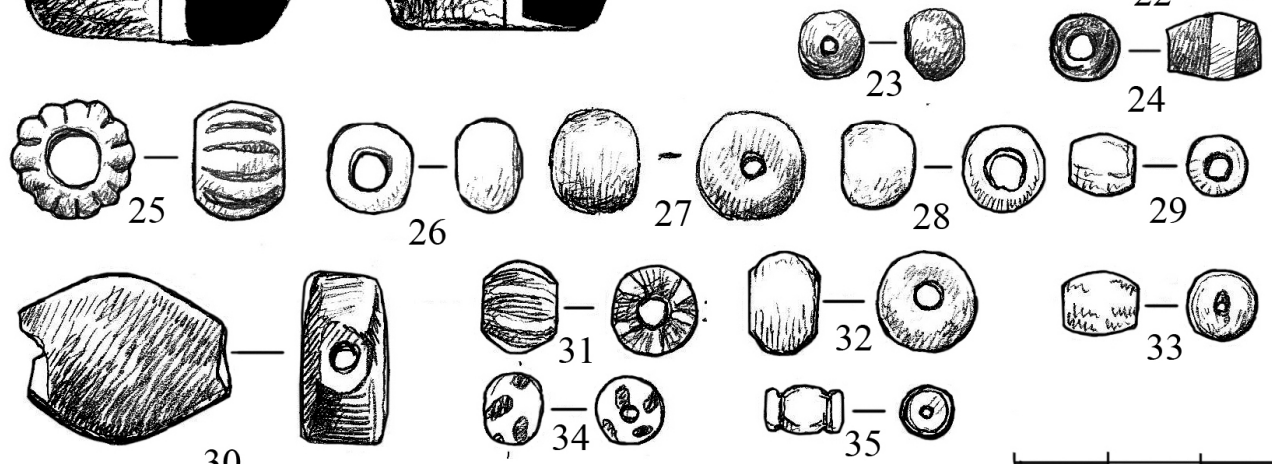

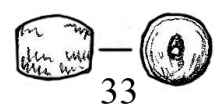

30

Puc. 16. Инвентарь и бусы из слоя погребений: 1-9 - изделия из бронзы: Бусы и пронизи: $15,16-19,21,23,26-28$ - одноцветное стекло; 20, 29, 35 - стекло с металлической прокладкой; 14, 22 - стекло с глазчатым орнаментом; 24 - полихромные; 34 - с пятнистым орнаментом; 31 - с продольно-полосатым орнаментом; 31 - с поперечно-линейным орнаментом; 30 - гагат; 25, 32 - фаянс; 33 - сердолик; 7 - бронзовая спиралевидная 
В заполнении слоя зафиксированы стенки и профильные части лощенных и нелощенных сосудов (рис. 11, 15-21; 12,3). Аналогичная лепная посуда выявлена ранее, на поселении Вилино (Рассадное), а также встречалась на Неаполе Скифском, Усть-Альминском городище и других поселениях позднескифской культуры ${ }^{31}$.

Бронзовые и железные изделия, украшения представлены фрагментами браслетов и гривн (рис. 15, 1, 3, 4, 7, 8), а так же пинцет, кольцо, детали крепления, фибулы, пряжки от ремня и др. (рис. $15,2,5 ; 16,1,3,5,6,8,9)$. Среди фрагментов браслетов и гривн, более достоверно можно выделить два браслета. Первый, тип III, (по Т.Н. Высотской), судя по размерам детский, и датируется от I в. до н.э.- по II в. н.э. ${ }^{32}$ Второй браслет - с окончаниями в виде змеиных головок. Он относится к типу III (по A.А. Труфанову) и встречается в период с первой половины или второй четверти I в. н.э. - до конца І в. н.э.33 Здесь же в слое найдены фрагменты колец с выступами, которые достаточно часто встречаются в погребениях позднескифской культуры Крыма (рис. 15, 6; 16, 4) 34. Такие кольца известны также в погребениях сарматской культуры Причерноморья, в Прикубанье и в Центральном Предкавказье в качестве амулетов и составленными из них ажурными подвесками в виде сфер первых веков нашей эры 35 . Здесь же найдены фрагменты бронзовой фибулы с овальной спинкой (рис. 16, 2). Данная фибула, по хронологии А.А. Труфанова, датируется 30/50 гг. н.э. 70 г. н.э. ${ }^{36}$; по датировкам В.В. Кропотова ${ }^{37}$ - ко второй половине I в. н.э. - началу II в. н.э.; К. Хелльстрем относит фибулы с овальной спинкой к типу 1C.138.

Среди разрушенных погребений обнаружены различные бронзовые детали креплений, кремневые орудия и отщепы.

В данном слое, выявлены бусы различных типов:

1. Из одноцветного стекла, типы $15,17,21,29,31,47,63,93,142,152$ (рис. 16, 10, $15,18,19,21,23,26,28 ; 17,3,6,10,17,18,21,28,29)^{39}$.

31 Колтухов С.Г., Зубар В.М., Миц В.Л. Вказ. пр. Рис. 4, 5, 6, 8; 5, 25-27; Высотская Т.Н. Неаполь... Рис. 34; Высотская Т.Н. Усть-Альминское городище и некрополь: монография. Киев: Киевская Академия Евробизнеса, 1994. Табл. 13, 1; 20, 62; Дашевская О.Д. Лепная керамика Неаполя и других скифских городищ Крыма // Материалы института археологии. 1958. № 64. Рис. 1, 1, 4, 7; Власов В.П. Лепная керамика Позднескифского Булганакского городища // Бахчисарайский историко-архитектурный сборник. 1997. Вып. 1. Табл. II.

32 Высотская Т.Н. Усть-Альминское городище... Рис. 33; Труфанов А.А. Хронология могильников Предгорного Крыма... Рис. 63, 6.

33 Труфанов А.А. К вопросу о хронологии браслетов с зооморфными окончаниями (по материалам крымских могильников позднескифского времени) // Труды Государственного исторического музея. 2001. Вып. 118. С. 75, рис. 1, 17.

34 Пуздровский А.Е. Крымская Скифия. II в.до н.э. - II в. н.э.... С. 162.

35 Пуздровский А.Е. Крымская Скифия. II в.до н.э. - II в. н.э.... Рис. 144, 2, 3, 29, 30;146, 3-5, 8-13, 16 ; Журавлев Д.В. «Браслеты» и кольца с выступами из позднескифских и сарматских памятников Северного Причерноморья // Проблемы истории, филологии, культуры. Москва, Магнитогорск, Новосибирск: Магнитогорский государственный технический университет. 2014. Вып. 2 (43). С. 70; Абрамова М.П. Центральное Предкавказье в сарматское время (III в. до н.э. - IV в. н.э.): монография. Москва, 1993. Рис. 29, 56, 60; Гущина И.И., Засецкая И.П. «Золотое кладбище» римской эпохи в Прикубанье: монография. Санкт-Петербург. 1994. Кат. 313, 317.

35 Труфанов А.А. Хронология могильников Предгорного Крыма... С. 128, 197.

36 Ibid. C. 128, 197.

37 Кропотов В.В. Фибулы сарматской эпохи: монография. Киев: Адеф-Украина, 2010. С. 168, рис. 51.

38 Hallcström K. Fibeln und Febeltracht der Sarmatischen Zeit im Nordshwarzmeergebiet. (2 jn. v. Chr. 3jh. n. Chr.) // Archäoljgie in evrasien. Band 39. Bonn, Hablt-Verlag, 2018. P. 67-68, tafl. 27.

39 Алексеева Е.М. Античные бусы Северного Причерноморья. Москва: Наука, 1982 (Свод археологических источников. Вып. Г1-12). С. 64-68, 71. 

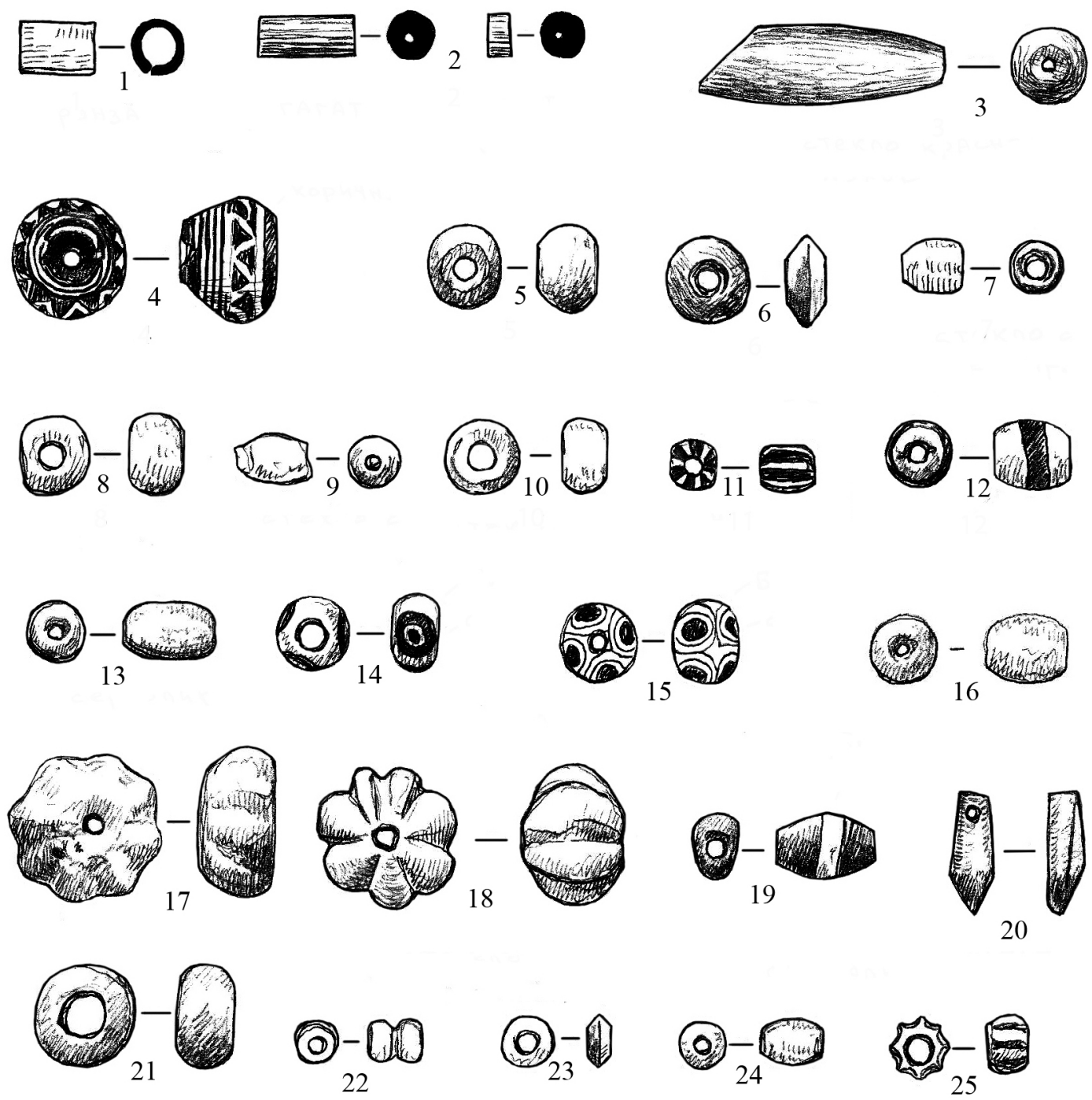

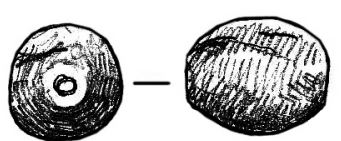

26<smiles>c1ccc(-c2ccccc2)cc1</smiles>
27

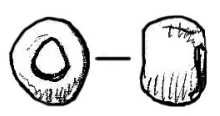

29

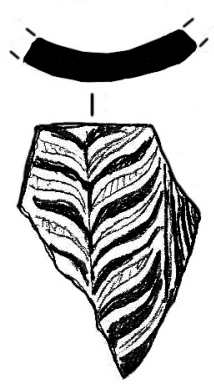

Рис. 17. Бусы из слоя погребений: 1 - бронза; 2 - бронза; 4 - с поперечно-полосатым орнаментом;

$3,6,10,17,18,21,26,28,29$ - одноцветное стекло; 7-9, 22, 24, 25, 27, - стекло с металлической прокладкой; 14, 15 - с глазчатым орнаментом;11 - с продольно-полосатым орнаментом;

12, 19 - с поперечной полосой; 5, 23 - фаянс; 13, 16 - сердолик; 20 - гагат; 30 - поперечно-линейным и перистым орнаментом 
2. С металлической прокладкой типы 1, 1а, 1,б, 26, 10, 22 (рис. 16, 29, 35, 17, 7-9)40. Многоцветные:

3. С пятнистым орнаментом типа 9 (рис. 16,22 ).

4. Глазчатые, типы 26a, 60a, 68, 79 (рис. 17, 14, 15; 16, 14) 41.

5. С продольно-полосатым орнаментом тип 195 (рис. 17, 11).

6. С поперечно-линейным и перистым орнаментом тип 341 (рис. 17, 30).

7. Со спиралевидным орнаментом тип 203а (рис. 16, 24; 17, 12, 19$)^{42}$.

8. Фаянсовые типы 3г, $11,16 г$ (рис. 16, 23, 25; 17, 23, 25) ${ }^{43 .}$

9. Сердоликовые тип 36 (рис. 16, 33; 17, 13, 16) 44 .

10. Гагатовые типы 26, 8б, 27a, 62 (рис. 16, 30; 17, 2) 45.

11. Бронзовые тип 5 и 31 (рис. 16, 7; 17, 1) ${ }^{46}$.

12. Особого внимания заслуживает полихромная бусина с волнисто-поперечнолинейным орнаментом бурого цвета с белыми линиями, редко встречающаяся, и которую можно отнести к типам 313-325*****. Данные для датировки достаточно широкие, но большая часть учтенных бус относится к римскому времени (рис. 17,4$)^{47}$. Близкие по орнаменту 2 бусины происходят из могильника у с. Дружное. Могилы с этими бусами датируются: склеп 58 - IV в. н.э; могила 80 - 286305 гг. н.э. 48 Подобные бусы встречаются в Европе в погребениях вербальской культуры ${ }^{49}$.

Основная масса выявленных в цистерне бус, встречается во II-І вв. до н.э. - в первые века н.э. в позднескифских и сарматских некрополях Крыма и Причерноморья (табл. 5).

Из предметов быта, среди инвентаря, найден фрагмент железного ножа и комок серы. Кроме этого можно отметить, находки точильного бруска и верхней части лепного грузила с отверстиями (рис. 11, 12).

В целом, несмотря на разрушенное состояние погребений и инвентаря, можно утверждать, что данные предметы характерны для некрополей позднескифской культуры Крыма и сармат Причерноморья конца ІІ в. до н.э. - первых веков н.э.

Анализ археологического материала позволяет выделить три периода функционирования каменного сооружения. Первый период - конец IV - начало III вв. н.э. Каменное монументальное сооружение построено и используется по своему непосред-

40 Алексеева Е.М. Античные бусы Северного Причерноморья. Москва: Наука, 1978 (Свод археологических источников. Вып. Г1-12). С. 29-32.

${ }^{41}$ Алексеева Е.М. Античные бусы Северного Причерноморья. Москва: Наука, 1975 (Свод археологических источников. Вып. Г1-12). С. 57, 59-68.

42 Ibid. C. 43; Алексеева Е.М. Античные бусы Северного Причерноморья... (1978). С. 53; Труфанов А.А. Хронология могильников Предгорного Крыма... Рис. 74, 33.

43 Алексеева Е.М. Античные бусы Северного Причерноморья... (1975). С. $31,33$.

${ }^{44}$ Алексеева Е.М. Античные бусы Северного Причерноморья... (1982). С. 16.

45 Алексеева Е.М. Античные бусы Северного Причерноморья... (1978). С. 10-11, 14, 18.

46 Алексеева Е.М. Античные бусы Северного Причерноморья... (1982). С. 23, 26.

***** Хочу выразить признательность А.А.Стояновой за консультации в вопросе определения некоторых типов бус.

47 Алексеева Е.М. Античные бусы Северного Причерноморья... (1978). С. 52.

48 Храпунов И.Н. Могильник Дружное (III-IV вв. нашей эры): монография. Lublin: Uniwersytety Marii Curie-Sklodovskiej, 2002. С. 65, 71, рис. 143, 41; 165, 24; Хайрединова Э.А. Бусы из могильника Дружное // Проблемы археологии древнего и средневекового Крыма. Симферополь. 1995. С. 5987.

49 Tempelemann-Maczynska M. Die Perlen der römischen Kaiserzeitund der frühen Phase der Völkerwanderungszeit im mitteleuropäischen Barbaricum // Mainz am Rhein. Philipp von Zabenrn. 1985. taf. 
ственному назначению, сбору и хранению дождевой воды, во время функционирования усадьбы, которая входит в состав хоры Херсонеса. Второй период - после значительного перерыва с конца II в. н.э. - начала I в. до н.э. - по II в. н.э. - цистерна используется в качестве погребального сооружения, как родовая усыпальница у поздних скифов. Возможно еще в первой половине III в. н.э. могло быть совершено погребение, что подтверждает находка фрагментов тарелки II типа50. Третий период после прекращения захоронений в цистерне, возможно в первой половине III в. н.э. или позже, используется в качестве подвала - верхняя часть сооружения.

Для сравнения с публикуемой цистерной можно рассматривать емкости, исследованные на территории Херсонеса эллинистического периода. Хотя по мнению некоторых исследователей «...возможности для сравнения... ограничены из-за того, что изучение и фиксация данных объектов произведены не на должном уровне»51. В Херсонесе и в других городах Причерноморья почти в каждом дворе мог быть колодец или цистерна для сбора и хранения воды ${ }^{52}$. И чаще всего колодец был конической (грушевидной) формы. Значительно реже встречались сооружения квадратной и прямоугольной формы.

Ряд таких сооружений на протяжении многих лет исследовали в Херсонесе. На территории XCVI квартала Херсонеса в 1993-1994 гг. раскопана цистерна, расположенная в южном углу двора. Сооружение было построено в твердой материковой скале 53 . Исследованы еще две цистерны из усадьбы «Басилида», что на хоре Херсонеса $^{54}$. Аналогичное сооружение раскопано в Пантикапее в царской резиденции 55 . В Ольвии, во дворе дома, выявлена водосборная цистерна квадратной в плане формы, построенная из камня и оштукатуренная. Она была связана водостоком с колодцем ${ }^{56}$. На Ольвийской агоре выявлено сооружение квадратной формы, построенное в традициях домостроя V-IV вв. до н.э. из обработанного известняка плотно подогнанного между собой. Конструкция входила в состав сложного гидротехнического сооружения в который вода подавалась из другого сооружения находившегося выше по уровню57. На Белозерском поселении, что в округе Ольвии, исследована цистерна конической формы 58 .

Однако более близкой по форме и архитектуре публикуемой цистерне, нам представляется несколько более поздний по времени объект. Это каменная цистерна

\footnotetext{
50 Труфанов А.А. Хронология могильников Предгорного Крыма... С. 153, рис. 17, 1, 4.

51 Золотарев М.И., Коробков Д.Ю., Ушаков С.В. О принципах изучения античных водосборных цистерн. Севастополь.1997. С. 26.

52 Белов Г.Д. Херсонес Таврический: историко-археологический очерк: монография. Ленинград: Государственный Эрмитаж, 1948. С. 88, рис. 18.

53 Золотарев М.И. и др. Указ. раб. С. 5, рис. 3.

54 Кузищин В.И., Иванчик А.И. «Усадьба Басилидов» в окрестностях Херсонеса Таврического. (Результаты работ Херсонесской историко-археологической экспедиции исторического факультета МГУ в 1976-1987 гг.) // Вестник древней истории. 1998. № 1. С. 215.

55 Толстиков В.П. Очерк градостроительной истории центрального района Пантикапея // Пантикапей и Фанагория. Две столицы Боспорского царства / Общ. ред. В. Кузнецов, В.П. Толстиков. Москва, 2017. С. 81, рис. 58.

56 Крыжицкий С.Д. Жилые ансамбли древней Ольвии IV-II вв. н.э. Киев: Наукова думка, 1971. С. 36, рис. 18.

57 Леви Е.И. К вопросу об Ольвийской агоре // Советская археология. 1954. № 21. С. 328-329, рис. 7.

58 Былкова В.П. Ранние постройки Белозерского поселения // Древнее Причерноморье. Сборник статей, посвященных 85-летию со дня рождения профессора П.О. Карышковского / гл. ред. В.Г. Кушнир. Одесса. 2006. С. 33-39.
} 
объемом 85,30 - 86 м $^{3}$ из средневекового Херсонеса обнаруженная во дворе жилого дома квартала VII. Она использовалась как емкость для сбора воды в IX-X вв. После прекращения функционирования она была приспособлена под тюрьму, а затем использовалась как подвал59. Форма, архитектура, особенности данного сооружения наиболее близки цистерне с поселения Вилино (Рассадное). Это каменное сооружение квадратной формы с двумя колоннами, на которые опиралось перекрытие сооружения. Схожесть конструктивных особенностей публикуемой цистерны и средневековой из Херсонеса, можно объяснить наличием устойчивых традиций в строительстве водосборных цистерн в античном мире, привнесенном из Средиземноморья в эллинистический период. Эти традиции формировались в районах, где воды в естественных источниках было недостаточно, начиная с эпохи бронзы (минойский период) и заканчивая средневековьем ${ }^{60}$.

Наличие аналогий публикуемой цистерне, имеются в значительном количестве на территории Греции. Это отдельные цистерны и системы, состоящие из нескольких резервуаров. Такие сооружения были изучены в таких греческих городах как Коринф, Афины - 150, Пергам - 149, известно несколько в Сиракузах ${ }^{61}$. Формы конструкции цистерн были различными: конической, прямоугольной, квадратной, открытые, закрытые. Чаще всего цистерны строили конической формы. По всей вероятности это зависело от наличия твердых пород грунта и размеров емкости. Идеально подходила скальная порода с естественными углублениями. Если таковых не было, приходилось строить из камня, что являлось более затратным, особенно если это были большие резервуары для общественного использования.

Близка по аналогии цистерне с поселения Вилино (Рассадное) емкость из города Лато, расположенного на острове Крит. К северу от храма на агоре исследовано квадратное в плане, каменное сооружение с дорическими колоннами, поддерживавшими перекрытие, глубиной 6 м и объемом 27,56 м 362 . Похожие цистерны известны на агоре древнего Дрероса (одна из них достигала глубины 8 м) и в других городах Крита - 15 емкостей несколько меньших размеров 63 . Или, например, общественная цистерна из города Орраона, что на Эпире, прямоугольной формы построенная в конце IV в. до н.э. Кладка стен сделана из хорошо обработанного камня (известняка), на дне имелась яма отстойник ${ }^{64}$.

59 Топография Херсонеса Таврического. Водосборная цистерна жилого дома в квартале VII (IXXI вв.) / Бернацки А.Б. Кленина Е.Ю. (ред) // Херсонесский сборник. Supplement. Вып. 1. Севастополь, 2006. С. 219.

${ }^{60}$ Antoniou G., Xarchakou R., Angelakis A.N. Water Cistern Systems in Greece from Minoan to Hellenistic Period // IWA 1st International Symposium on Water and Wastewater Technologies in Ancient Civilizations, Iraklio. Greece. 28-30 October. 2006. P. 458.

61 Thompson H.A. Two Centuries of Hellenistic Pottery // Hesperia. 1934. III. P. 330, 345-346; Edwards G.R. Corinthian Hellenistic Pottery // Corinth. Vol. VII. Part III, Princeton. New Jersew, 1975. P. 206; Antoniou G., Xarchakou R., Angelakis A.N. Op. cit. P. 469; Klinsburg P., Finné M. Modelling the freshwater supply of cisterns in ancient Greece // Water History. September 2018. Vol. 10. Issue 2-3, P. 115. DOI: https://doi.org/10.1007/s12685-017-0209-y; Crouch D.P. Planning water management for an ancient Greek city // Hydrological Processes and Water Management in Urban Antes (Proceedings of the Duisberg Symposium. April 1988). IAHS Publ. No. 198. 1990.P. 276.

62 Antoniou G., Xarchakou R., Angelakis A.N. Op. cit. P. 458-459, figure 2.

${ }^{63}$ Angelakis A.N. Evolution of rainwater harvesting and use in Grette hellas through the millenia // Proceedings of the 13 international Conference on Environmental Science and Technology. Athens. Greese. 5-7 September 2013. P. 5, 1.

64 Antoniou G., Xarchakou R., Angelakis A.N. Op. cit. P. 461. 
В трудах римского архитектора Витрувия описаны традиции сооружения водосборных цистерн. Он рекомендовал строить сразу несколько емкостей и соединять их между собой водопроводом. Вода в первой цистерне собиралась и очищалась в процессе оседания грязи. В другие сооружения через каналы (водопроводы) вода поступала уже очищенная65.

Должностные лица, ответственные за благоустройство в древнегреческих городах, а также за бесперебойное функционирование систем водообеспечения и водо-

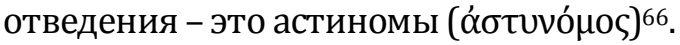

По свидетельству Аристотеля, они должны были «беспокоиться о городских и пригородных источниках, чтобы они были чистыми, и чтобы каналы... не засорялись... Обязаны переписать все имеющиеся цистерны... и следить за тем, чтобы хозяева держали цистерны закрытыми, и вода не была засорена...»67.

В древнегреческих городах не везде хватало природных источников воды для достаточного обеспечения населения. Многие города довольствовались резервуарами или цистернами для сбора и хранения дождевой воды. Емкости сообщались между собой с помощью каналов или керамических водопроводов в целях очистки ${ }^{68}$. На территории эллинистического мира достаточно большое внимание уделялось водной безопасности и строительство цистерн для сбора дождевой воды играло важную роль в жизнеобеспечении населения городов, усадеб эллинистического мира и находилось под особым контролем администрации полисов.

\section{Выводы.}

Исследованное в 2008 г. сооружение было построено в классических традициях древнегреческой архитектуры в конце IV в. до н.э. в качестве цистерны для сбора и хранения дождевой воды. Оно использовалось до начала III в. до н.э., что является синхронным со временем функционирования усадьбы и подтверждается керамическим материалом как с поселения69, так и с цистерны. На поселении (после гибели античной усадьбы) со второй половины III в. н.э. - до первой половины II в. до н.э. проживает какое-то новое население, что при дальнейших исследованиях на городище подтверждается культурным слоем и керамическим материалом и клеймами ${ }^{70}$. Но цистерна, в это время, видимо не использовалась. Уже с конца II в. до н.э -

65 Витрувий. Десять книг об архитектуре / пер. Ф.А. Петровского. Москва: Искусство, 1936. VIII, VI. 15.

66 Ручинская О.А. Культура и общество греческих городов Северного Причерноморья (VI в. до н.э. - IV в. н.э.): монография. Харьков: Майдан, 2017. С. 59-60.

${ }^{67}$ Аристотель. Политика Сочинения в 4-х тт. / Пер. С.А. Жебелева. Москва: Мысль, 1983. T. 4, II, 50; Аристотель. Сочинения в 4-х т. / Пер. под ред. А.И. Доватура. Москва: Мысль, 1984, Т. 4, VI, 5, 3.

68 Эллинистическая техника / И.И. Толстой (ред). Москва, Ленинград, 1948. С. 171.

69 Колтухов С.Г., Зубар В.М., Миц В.Л. Вказ. пр. С. 91.

70 Пуздровский А.Е., Медведев Г.В., Соломоненко А.Е., Труфанов А.А. Охранные исследования Альминской экспедиции в 2008 г. С. 249; Пуздровский А.Е. и др. Охранные исследования на городище Вилино в 2009 г. // Археологічні дослідження в Україні в 2009. Київ, 2010. С. 356; Пуздровский А.Е., Медведев Г.В., Ляшук П.М., Охранные исследования на городище Вилино (Рассадное) (2011). С. 281-282; Пуздровский А.Е., Медведев Г.В., Ляшук П.М., Охранные исследования на городище Вилино (Рассадное) (2012). С. 104-105; Пуздровский А.Е., Ляшук П.М., Масюта Д.А., Медведев Г.В. Охранные исследования на городище Вилино (Рассадное) (2012). С. 80-81; Пуздровский А.Е., Ляшук П.М., Масюта Д.А., Медведев Г.В. Охранные исследования на городище Вилино (Рассадное) (2012). Пуздровский А.Е., Ляшук П.М., Масюта Д.А., Медведев Г.В. Охранные исследования на городище Вилино (Рассадное) (2014). С. 71-72. 
начала I в. до н.э. население позднескифской культуры использует цистерну как подземное погребальное сооружение (склеп). Судя по инвентарю погребений, как склеп сооружение могло функционировать до конца II в. н.э. возможно до начала первой половины III в. н.э.

После прекращения использования как склепа, сооружение было ограблено и единовременно засыпано, причем преимущественно культурным слоем эллинистического времени. Засыпалось сооружение с севера, востока и запада, что подтверждается стратиграфическими разрезами и отсутствием слоя IV-III вв. до н.э. в северной части раскопа, где он выбран до материка. В верхней части заполнения лежали блоки, вероятно происходящие из оборонительной стены или башни. Затем к западной стене цистерны пристраивают кладки, сложенные на грязевом растворе из вторично использованного камня. Часть объема цистерны в это время могла использоваться в качестве подвала, вход в который, обрамленный порогом - с запада. Позже сооружение грабилось, как минимум дважды. Первый раз - в древности, а второй - в 2006-2007 гг., о чем свидетельствуют раздробленные кости погребений и наличие остатков инвентаря погребений на разной глубине, особенно в восточной части, где зафиксирована грабительская яма.

Ситуацию с использованием каменной цистерны в качестве погребального сооружения можно объяснить удобством для захоронений - как родового склепа при отсутствии необходимости строить новое сооружение, что требовало значительных затрат. Тем более что опыт использования каменных склепов эллинистического времени в Предгорном Крыму населению позднескифской культуры был известен ${ }^{71}$.

Сложно объяснить факт совершения захоронений на поселении, где проживало население позднескифской культуры в это же время. Тем более, что к юго-западу от поселения были исследованы курганы эпохи бронзы с впускными погребениями I в. до н.э. - I в. н.э. Одно из них содержало «элитное погребение» с богатым инвентарем. Кроме этого, недалеко от поселения исследован грунтовый склеп с групповыми захоронениями этого же времени ${ }^{72}$. Грунтовый склеп может свидетельствовать о наличии рядом с памятником некрополя.

Монументальное сооружение (цистерна), построенное в классических традициях древнегреческой архитектуры, является уникальным для сельской округи у границ Херсонесского государства73. На окраинах античного государства и границах с варварским миром, наличие таких объектов кажется маловероятным. А кроме этого, необходимо отметить, что исходя из изученных археологических данных и письменных источников, можно предполагать на поселении наличие, еще как минимум,

\footnotetext{
71 Михлин Б.Ю., Бирюков А.С. Склеп с уступчатым перекрытием в некрополе Керкинитиды // Население Крыма и культура в первые века н.э. Киев, 1983. С. 42; Катюшин Е.А. Склеп первых веков н.э. из села Льговское // Материалы по археологии, истории и этнографии. 1993. Вып. III. С. Рис. 1; Кропотов В.В., Лесков А.М. Курган с «коллективным погребением» у с. Кринички (по материалам работ 1957 г.) // Культура народов Причерноморья (Симферополь). 2006. № 84. Рис. 1; 2; Пуздровский А.Е. Крымская Скифия. ІІ в.до н.э. - II в. н.э... Рис. 8; 9; 53; Пуздровский А.Е., Труфанов А.А., Медведев Г.В. Каменный подкурганный склеп с «коллективными» захоронениями у с. Брянское в Юго-Западном Крыму // Археологический альманах. 2010. № 22. Рис. 1; 2.

72 Волошинов А.А., Лобода И.И. Бахчисарайский историко-культурный заповедник и археологические исследования в Юго-Западном Крыму // Древние сокровища Юго-Западного Крыма. Каталог выставки / науч. ред. Ю.П. Зайцев. Симферополь, 2005. С. 26.

73 Ланцов С.Б. П.Н. Шульц в изучении античных памятников Северо-Западного Крыма. Проблема определения границ Херсонесского государства в IV-II вв. до н.э. // У Понта Эвксинского (памяти П.Н. Шульца) / ред. сост. С.Г. Колтухов, С.Б. Ланцов, А.Е. Пуздровский. Симферополь, 2004. С. 59, 61.
} 
одной цистерны. С предполагаемой цистерной она могла быть соединена водопроводом или каналом. Что важно для очистки воды в целях санитарной безопасности. Данное предположение можно проверить только при дальнейших исследованиях на памятнике.

Цистерна может быть важным объектом, при исследовании слабо изученных вопросов связанных с водоснабжением древнегреческих полисов Северного Причерноморья.

Поселение Вилино (Рассадное) может стать одним из базовых объектов для разработки вопросов хронологии и определения границ Херсонесского государства, торговых связей с античными центрами Причерноморья и Средиземноморья, грековарварских взаимоотношений в Западном Крыму эпохи эллинизма и римского времени и т.д.

\section{REFERENCES}

Abramov, A.P. (1993). Antichnye amfory. Periodizatsiia i khronologiia [Antique amphoras. Periodization and chronology]. Bosporskii sbornik, 3, 4-135 [in Russian].

Abramova, M.P. (1993). Tsentralnoe Predkavkaze v sarmatskoe vremia III v. do n.e. - IV v. n.e. [Central Ciscaucasia in Sarmatian time (III century BC - IV century AD)]. Moskva [in Russian].

Alekseeva, E.M. (1975). Antichnye busy Severnogo Prichernomoria [Antique beads of the Northern Black Sea region]. Moskva: Nauka (Svod arkheologicheskikh istochnikov, G1-12) [in Russian].

Alekseeva, E.M. (1978). Antichnye busy Severnogo Prichernomoria [Antique beads of the Northern Black Sea region]. Moskva: Nauka (Svod arkheologicheskikh istochnikov, G1-12) [in Russian].

Alekseeva, E.M. (1982). Antichnye busy Severnogo Prichernomoria [Antique beads of the Northern Black Sea region]. Moskva: Nauka (Svod arkheologicheskikh istochnikov, G1-12) [in Russian].

Angelakis, A.N. (2013). Evolution of rainwater harvesting and use in Grette hellas through the millennia. In: Proceedings of the 13 international Conference on Environmental Science and Technology. 57 September. Athens, Greece [in English].

Antoniou, G, Xarchakou, R, Angelakis, A.N. (2006). Water Cistern Systems in Greece from Minoan to Hellenistic Period. In: IWA 1st International Symposium on Water and Wastewater Technologies in Ancient Civilizations. 28-30 October (457-462). Iraklio, Greece [in English].

Belov, G,D. (1948). Khersones Tavricheskii: istoriko-arkheologicheskii ocherk [Tauric Chersonesos: a historical and archaeological essay]. Leningrad: Gosudarstvennyi Ermitazh [in Russian].

Bernatski, A.B. \& Klenina, E.Yu. (Ed.). (2006). Topografiia Khersonesa Tavricheskogo. Vodosbornaia tsisterna zhilogo doma v kvartale VII (IX-XI vv.). [Topography of Tauric Chersonesos. Water collection tank of a residential building in quarter VII (IX-XI centuries)]. Khersonesskii sbornik (Sevastopol), 1 [in Russian].

Buiskikh, S.B. (2012). Seraia goncharnaia keramika Bospora (popytka osmysleniia na fone Severnogo Prichernomoria) [Gray pottery ceramics of Bosporus (an attempt to make sense against the background of the Northern Black Sea region)]. Bosporskie issledovaniia, 26, 22-58 [in Russian].

Bylkova, V.P. (2006). Rannie postroiki Belozerskogo poseleniia [Early constructions of Belozersky settlement]. In: Kushnir V.G. (Ed.). Drevnee Prichernomore. Sbornik statei posviashchennykh 85-letiiu so dnia rozhdeniia professora P.O. Karyshkovskogo (pp. 33-39). Odessa [in Russian].

Crouch, D.P. (1990). Planning water management for an ancient Greek city. In: Hydrological Processes and Water Management in Urban Antes (Proceedings of the Duisberg Symposium. April 1988). IAHS Publ. [in English].

Dashevskaia, 0.D. (1958). Lepnaia keramika Neapolia i drugikh skifskikh gorodishch Kryma [Stoneware ceramics of Naples and other Scythian ancient settlements of Crimea]. Materialy instituta arkheologii, 64, 248-271 [in Russian].

Dashevskaia, O.D. (1980). O skifskikh kurilnitsakh [About Scythian incense burners]. Sovetskaia arkheologiia, 1, 18-29 [in Russian].

Dashevskaia, O.D. (1991). Pozdnie skify v Krymu [Late Scythians in Crimea]. Moskva: Nauka (Svod akheologicheskikh istochnikov. D1-7) [in Russian].

Danilchenko, S,A. (2013). Stolovaia keramika iz raskopok Nimfeia (2008-2012) [Dining ceramics from the excavation of Nymphea (2008-2012)]. In: Bosporskii fenomen. Greki i varvary na Evraziisom perekrestke. Materialy mezhdunarodnoi konferentsii (pp. 161-166). Sankt-Peterburg [in Russian]. 
Edwards, G.R. (1975). Corinthian Hellenistic Pottery. Corinth. Princeton. New Jersey [in English].

Egorova, T.N. (2009). Chernolakovaia keramika IV-II vv. do n.e. s pamiatnikov Severo-Zapadnogo Kryma [Black-lacquered ceramics IV-II cent. BC. from the monuments of the North-Western Crimea]. Moskva: Moskovskii gosudarstvennyi universitet [in Russian].

Egorova, T.N. (2014). Novaia ranneellinisticheskaia usadba na gorodishche Chaika i ee mesto v strukture poseleniia [The New Early Hellenistic Farmstead on «Chaika» Settlement and Its Place in Its Structure]. Stratum plus, 3, 303-323 [in Russian].

Egorova, T.N. (2015). Chernolakovaia keramika V-IV vv. do n.e. s procherchennym shtampovannym ornamentom iz raskopok Pantikapeia [Black-lacquered ceramics of the 5th -4 th centuries. BC with a drawn stamped ornament from the excavation of Pantikapaion]. In: Gabelko, O.L. (ed.). S Mitridata duet veter Bospor i Prichernomore v antichnosti. K 70-ti letiyu V.P. Tolstikova (pp. 63-67). Moskva: Universitet Dmitriia Pozharskogo [in Russian].

Finkielsztejn, G. (2001). Chronologie detaillee et revise des eponymes amphoriqes rhodiens, de 270 a 108 av. J.-C. environ. Preier bilan. Bar International Series, 990 [in French].

Grakov, B.N. (1928). Drevne-grecheskie keramicheskie kleima s imenami astinomov [Ancient Greek ceramic stigma with the names of astinomes]. Moskva: RANION [in Russian].

Gushchina, I.I. \& Zasetskaia, I.P. (1994). Zolotoe kladbishche rimskoi epokhi v Prikubane ["Golden Cemetery» of the Roman era in Prikubanye]. Sankt-Peterburg [in Russian].

Hallcström, K. (2018). Fibeln und Febeltracht der Sarmatischen Zeit im Nordshwarzmeergebiet. (2 jn.v. Chr. - 3jh. n. Chr.). Archäoljgie in evrasien. Bonn: Hablt-Verlag [in German].

Katiushin, E.A. (1993). Sklep pervykh vekov n e iz sela Lgovskoe [Cry of the first centuries n.e from the village of Lgovsky]. Materialy po arkheologii, istorii i etnografii Tavriki, III, 14-16 [in Russian].

Kats, V.I. (2007). Grecheskie keramicheskie kleima epokhi klassiki ellinizma opyt kompleksnogo izucheniia [Greek ceramic stigmas of the Hellenistic classic era (experience of complex study)]. Bosporskie issledovaniia, 18 [in Russian].

Khairedinova, E.A. (1995). Busy iz mogilnika Druzhnoe [Beads from Druzhnoe burial ground]. Problemy arkheologii drevnego i srednevekovogo Kryma (Simferopol), 59-87 [in Russian].

Khrapunov, I.N. (2002). Mogilnik Druzhnoe (III-IV v. nashei ery) [Burial Druzhny (III-IV century AD)]. Lublin: Uniwersytety Marii Curie-Sklodovskiej [in Russian].

Klinsburg, P. \& Finné, M. (2018). Modelling the freshwater supply of cisterns in ancient Greece. Water History, 2-3, 113-131. DOI: https://doi.org/10.1007/s12685-017-0209-y [in English].

Koltukhov, S.H., Zubar, V.M. \& Myts, V.L. (1992). Novyi raion khory Khersonesa ellinistychnoho period [The new district of choirs of Chersonesos of the Hellenistic period]. Arkheolohiia, 2, 85-95 [in Ukrainian].

Kropotov, V.V. (2010). Fibuly sarmatskoi epokhi [Fibulae Sarmatian era]. Kiev: Adef-Ukraina [in Russian].

Kropotov, V.V. \& Leskov A,M. (2006). Kurgan s kollektivnym pogrebeniem u s Krinichki po materialam rabot 1957 god [Mound with a «collective burial» at with. Krinichki (based on the works of 1957)]. Kultura narodov Prichernomoria, 84, 25-39 [in Russian].

Kryzhitskii, S.D. (1971). Zhilye ansambli drevnei Olvii IV-II vv. n.e. [Residential ensembles of ancient Olbia IV-II centuries AD]. Kiev: Naukova dumka [in Russian].

Kryzhitskii, S.D. (1993). Arkhitektura antichnykh gorodov Severnogo Prichernomoria [The architecture of the ancient cities of the Northern Black Sea]. Kiev: Naukova dumka [in Russian].

Kuzishchin, V.I. \& Ivanchik, A.I. (1998). «Usadba Basilidov» v okrestnostiakh KHersonesa Tavricheskogo (Rezultaty rabot KHersonesskoi istoriko-arkheologicheskoi ekspeditsii istoricheskogo fakulteta MGU v 1976-1987 gg.) [«Basilides Manor» in the vicinity of Tauric Chersonesos. (Results of the work of the Chersonesus Historical and Archaeological Expedition of the Faculty of History of the Moscow State University in 1976-1987)]. Vestnik drevnei istorii, 1, 205-233 [in Russian].

Lantsov, S.B. (2004). P.N. Shults v izuchenii antichnykh pamiatnikov Severo-Zapadnogo Kryma Problema opredeleniia granits Khersonesskogo gosudarstva v IV-II vv. do n.e. [Schultz in the study of ancient monuments of the North-Western Crimea. The problem of determining the boundaries of the Chersonesus in the IV-II centuries BC]. In: U Ponta Evksinskogo (pamiati P.N. Shultsa) (pp. 58-68). Simferopol [in Russian]

Levi, E.I. (1954). K voprosu ob Olviiskoi agore [To the question of the Olbia Agora]. Sovetskaia arkheologiia, 21, 319-342 [in Russian].

Meliukova, A.I. (1958). Pamiatniki skifskogo vremeni lesostepnogo Srednego Podnestrovia [Monuments of the Scythian time of the forest-steppe Middle Dniester]. Materialy instituta arkheologii, 64, 5-102 [in Russian]. 
Mikhlin, B.Yu. \& Biriukov, A.S. (1983). Sklep s ustupchatym perekrytiem v nekropole Kerkinitidy [Crypt with a stepped ceiling in the necropolis of Kerkinitida]. Naselenie Kryma i kultura $v$ pervye veka n.e. (pp. 28-45). Kiev: Naukova dumka [in Russian].

Monakhov, S.Yu. (1989). Amfory Khersonesa Tavricheskogo IV-II vv. do n.e. Opyt sistemnogo analiza [Amphoras of Chersonesos of the Tauric IV-II cc. BC. Experience system analysis]. Saratov: Izdatelstvo Saratovskogo universiteta [in Russian].

Monakhov, S.Yu. (2003). Grecheskie amfory v Prichernomore. Tipologiia amfor vedushchikh tsentroveksporterov v keramicheskoi tare [Greek amphoras in the Black Sea region: typology of amphoras of the leading centers exporting goods in ceramic containers]. Moskva, Saratov: Kimmerida Izdatelstvo Saratovskogo universiteta [in Russian].

Pogrebova, N.N. (1958). Pozdneskifskie gorodishcha na Dnepre (Gorodishche Znamenskoe i Gavrilovskoe) [Late Scythian settlements on the Dnieper (Znamenskoe and Gavrilovskoye Settlement)]. Materialy instituta arkheologii, 64, 103-247 [in Russian].

Puzdrovskii, A.E. (2007). Krymskaia Skifiia II v. do n.e. - II v. n.e. Pogrebalnye pamiatniki [Crimean Scythia in II century BC - II century AD. Funerary monuments]. Simferopol: Biznes-Inform [in Russian].

Puzdrovskii, A.E., $\quad$ Medvedev, G.V., Solomonenko, A.E. \& Trufanov, A.A. (2009). Okhrannye issledovaniia Alminskoi ekspeditsii v $2008 \mathrm{~g}$. [Protection's researches investigations of the Alma expedition in 2008]. Arkheolohichni doslidzhennia v Ukraini 2008, 248-250 [in Russian].

Puzdrovskii, A.E., Medvedev, G.V. \& Liashuk, P.M. (2010). Okhrannye issledovaniia na gorodishche Vilino v $2009 \mathrm{~g}$. [Protection's researches at Vilino site in 2009]. Arkheolohichni doslidzhennia $v$ Ukraini 2009, 355-356 [in Russian].

Puzdrovskii, A.E., Trufanov, A.A. \& Medvedev, G.V. (2010). Kamennyi podkurgannyi sklep s kollektivnymi zakhoroneniiami u s Brianskoe v Yugo-Zapadnom Krymu [Stone undermound's crypt with «collective» burials in with Brianskoe in the South-Western Crimea]. Arkheologicheskii almanakh, 22, 119-206 [in Russian].

Puzdrovskii, A.E., Medvedev, G.V. \& Liashuk, P.M. (2011). Okhrannye issledovaniia na gorodishche Vilino (Rassadnoe) [Protection's researches on the site of Vilino (Rassadnoye)]. Arkheolohichni doslidzhennia v Ukraini 2010, 281-282 [in Russian].

Puzdrovskii, A.E., Medvedev, G.V. \& Liashuk, P.M. (2012). Okhrannye issledovaniia na gorodishche Vilino (Rassadnoe) [Protection's researches on the site of Vilino (Rassadnoye)]. Arkheolohichni doslidzhennia v Ukraini 2011, 104-105 [in Russian].

Puzdrovskii, A.E., Liashuk, P.M., Masiuta, D.A. \& Medvedev, G.V. (2013). Okhrannye issledovaniia na gorodishche Vilino (Rassadnoe) [Protection's researches on the site of Vilino (Rassadnoye)]. Arkheolohichni doslidzhennia v Ukraini 2012, 80-81 [in Russian].

Puzdrovskii, A.E., Medvedev, G.V., Liashuk, P.M. \& Masiuta, D.A. (2014). Okhrannye issledovaniia na gorodishche Vilino Rassadnoe [Protection's researches on the site of Vilino (Rassadnoe)]. Arkheolohichni doslidzhennia v Ukraini 2013, 71-72 [in Russian].

Puzdrovskii, A.E. \& Trufanov, A.A. (2016). Polevye issledovaniia Ust-Alminskogo nekropolia $v 2008$ 2014 gg. Ust-Alminskoe gorodishche i nekropol v Yugo-Zapadnom Krymu [Field studies of the UstAlminsky necropolis in 2008-2014. Ust-Alma site fortification and necropolis in South-western Crimea]. Simferopol-Moskva [in Russian].

Ruchinskaia, O.A. (2017). Kultura i obshchestvo Grecheskikh gorodov Severnogo Prihernomoria (VI v. do n.e. - IV v. n.e.) [Culture and society Greek towns northern Blown Sea (VI century BC - IV century AD)]. Kharkov: Maidan [in Russian].

Shelov, D.B. (1978). Uzkogorlye svetloglinianye amfory pervykh vekov nashei ery. Klassifikatsiia i khronologiia [Narrow light-lined amphoras of the first centuries AD. Classification and chronology]. Kratkie soobshcheniia instituta arkheologii, 156, 16-21 [in Russian].

Sheiko, I.N. (2014). Pergamskie i Efesskie svetilniki iz Olvii (import i mestnye imitatsii) [Pergamon and Ephesus lamps from Olbia (Import and local imitations)]. Problemy istorii filologii kultury, 2, 108-123 [in Russian].

Sheiko, Y.N. (2015). Svitylnyky Olvii (kinets VII - I st. do n.e.) [Lights of Olbia (the end of VII - I centuries $\mathrm{BC})$ ]. (Candidate's thesis). Kyiv [in Ukrainian].

Sinika, V.S., Menshikova, V.A. \& Telnov, N.P. (2014). Lepnye kurilnitsy iz pamiatnikov Severnogo Prichernomoria v IV-I vv. do n.e. [Hand-Molded Incense Cups from the Northern Black Sea Coast Sites of 4 th-1 st Centuries BC]. Stratum plus, 3, 65-101 [in Russian].

Symonovich, E.A. (1983). Naselenie stolitsy pozdneskifskogo tsarstva po materialam Vostochnogo nekropolia Neapolia skifskogo [Population of the capital of the late Scythian kingdom (according to materials from the Eastern Necropolis of Scythian Naples)]. Kiev: Naukova dumka [in Russian]. 
Tolstikov, V.P. (2017). Ocherk gradostroitelnoi istorii tsentralnogo raiona Pantikapeia [Molded burners from the monuments of the Northern Black Sea region in the IV-I centuries BC]. In: Pantikapei $i$ Fanagoriia. Dve stolitsy Bosporskogo tsarstva, (pp. 69-84). Moskva [in Russian].

Tempelemann-Maczynska, M. (1985). Die Perlen der römischen Kaiserzeitund der frühen Phase der Völkerwanderungszeit im mitteleuropäischen Barbaricum. Mainz am Rhein, Philipp von Zabenrn, taf. 8 [in German].

Thompson, H.A. (1934). Two Centuries of Hellenistic Pottery. Hesperia, III, 311-475 [in English].

Tolstoi, I.I. (ed.). (1948). Ellinisticheskaia tekhnika [Hellenistic technique]. Moskva-Leningrad [in Russian].

Trufanov, A.A. (1997). Tipologiia krasnolakovykh tarelok s vertikalnym bortikom po materialam mogilnikov Yugo-Zapadnogo i Tsentralnogo Kryma [Typology of red-lacquered plates with a vertical side (based on materials from the cemeteries of the South-Western and Central Crimea)]. Bakhchisaraiskii istoriko-arkheologicheskii sbornik, 1, 181-192 [in Russian].

Trufanov, A.A. (2001). K voprosu o khronologii brasletov s zoomorfnymi okonchaniiami pomaterialam krymskikh mogilnikov pozdneskifskogo vremeni [To the question of the chronology of bracelets with zoomorphic endings (based on materials from the Crimean burial grounds of the Late Scythian time)]. Trudy gosudarstvennogo istoricheskogo muzeia, 118, 71-78 [in Russian].

Trufanov, A.A. (2009). Khronologiia mogilnikov Predgornogo Kryma I v. do n.e. - III v. n.e. [Chronology of the burial grounds of the Piedmont Crimea. I century BC - III century AD]. Stratum Plus, 4, 117-328 [in Russian].

Trufanov, A.A. (2011). Metallicheskie amulety-podveski Severnogo Prichernomoria pervykh vekov n.e. [Metal Amulets-Pendants from Northern Black Sea Coast of the First Centuries AD]. Stratum plus, 4, 225-270 [in Russian].

Ushakov, S.V. (2010). Keramicheskii kompleks Khersonesa Tavricheskogo (po materialam rabot BSPPrichernomorskogo proekta u Baziliki 1935 g.) [Ceramic complex of Tauric Chersonesos]. Materialy po arkheologii i istorii antichnogo i srednevekovogo Kryma, II, 7-26 [in Russian].

Vlasov, V.P. (1997). Lepnaia keramika Pozdneskifskogo Bulganakskogo gorodishcha [Early constructions of Belozersky settlement]. Bakhchisaraiskii istoriko-arkheologicheskii sbornik, 1, 204303 [in Russian].

Vnukov, S.Yu. (2003). Prichernomorskie amfory I v. do n.e. - II v. n.e. [Black Sea amphorae of I century BC - II century AD]. Moskva: Institut arkheologii Rossiiskoi Akademii nauk [in Russian].

Vnukov, S.Yu. (2006). Prichernomorskie amfory I v. do n.e. - II v. n.e. Petrografiia, khronologiia, problemy torgovli [Black Sea amphoras of I century BC - II century AD. Petrography, chronology, problems of trade]. Sankt-Peterburg: Aleteiia [in Russian].

Voloshinov, A.A. \& Loboda, I.I. (2005). Bakhchisaraiskii istoriko-kulturnyi zapovednik i arkheologicheskie issledovaniia v Yugo-Zapadnom Krymu [Bakhchisarai Historical and Cultural Reserve and Archaeological Research in the South-Western Crimea]. In: Drevnie sokrovishcha YugoZapadnogo Kryma. Katalog vystavki (pp. 26-27). Simferopol [in Russian].

Vysotskaia, T.N. (1979). Neapol - stolitsa gosudarstva pozdnikh ckifov [Naples is the capital of the state of the late Scythians]. Kiev: Naukova dumka [in Russian].

Vysotskaia, T.N. (1994). Ust-Alminskoe gorodishche i nekropol [Ust-Alminskoe Settlement and Necropolis]. Kiev: Kievskaia Akademiia Evrobiznesa [in Russian].

Zhuravlev, D.V. (2007). Pontiiskaia sigillata iz mogilnikov Belbek III i Belbek IV v Yugo-Zapadnom Krymu [Pontic sigillata from the burial grounds Belbek III and Belbek IV in the South-Western Crimea]. Bosporskie issledovaniia, 16, 366-448 [in Russian].

Zhuravlev, D.V. (2014). Braslety i koltsa s vystupami iz pozdneskifskikh i sarmatskikh pamiatnikov Severnogo Prichernomoria [«Bracelets» and rings with protrusions from the Late Scythian and Sarmatian monuments of the Northern Black Sea region]. Problemy istorii filologii kultury, 2 (43), 5985 [in Russian].

Zhuravlev, D.V. \& Turova, N.P. (2012). Antichnye glinianye svetilniki Yaltinskogo istoriko-literaturnogo muzeia [Antique clay lamps of the Yalta History and Literature Museum]. Bosporskie issledovaniia, 26, 335-400 [in Russian].

Zolotarev, M.I., Korobkov, D.Yu. \& Ushakov, S.V. (1997). O printsipakh izucheniia antichnykh vodosbornykh tsistern [On the principles of studying ancient drainage tanks]. Sevastopol [in Russian]. 


\section{Gennadii Medvedev}

(Institute of Archeology of Crimea, Simferopol, Autonomous Republic of Crimea)

ORCID: https://orcid.org/0000-0003-0977-8321

\section{Rainwater Cistern of Hellenistic Period from the Settlement of Vilino (Rassadnoie) - as a Burial Structure of the Late Scythian Culture}

The information about the rainwater cistern of the Hellenistic period - the end of the $4^{\text {th }}-$ the beginning of the $3^{\text {rd }}$ century BCE is presented in the paper. The construction was studied at the settlement of Vilino (Rassadnoie) in 2008 in the Bakhchisarai Raion (District) in the Crimea. It was situated at the eastern wall inside the estate, which was a part of the choir of Chersonesus. In the Late Scythian period, the construction was reused as a burial structure (ossuary) - from the end of the $2^{\text {nd }}$ - beginning of the $1^{\text {st }}$ century BCE - till the end of the $2^{\text {nd }}$ century CE - the first half of the $3^{\text {rd }}$ century CE. About 30 people were buried in the ossuary. Then the ossuary was robbed and covered with resedimented occupation layer from the settlement. The cistern was robbed more than once, as testified by the diggings, ancient and modern. After stopping using the structure as an ossuary, its upper part started to be used as a basement.

The fragments of archaeological material of the $4^{\text {th }}-2^{\text {nd }}$ centuries BCE were found in the construction. Ceramic material indicates the wide trade links with the Black Sea and Mediterranean ancient centers (Sinop, Rhodos, Attica, Knidos, Ephesus, etc.). The remains of burial equipment are typical for the Late Scythian culture of Crimean Piedmont and the Sarmatian culture of the Northern Black Sea region.

It is difficult to explain the situation of using the object as an ossuary at the settlement where the population lived.

The cistern was constructed in the classical traditions of ancient Greek architecture and has analogies at the sites of ancient Greece and the Northern Black Sea region. Nevertheless, it is a unique object located on the choir of the Chersonesus state and the border with the barbarian world. Judging by archaeological and written materials, at least one more cistern could be present at the settlement.

The construction could be an important object in the study of poorly studied issues related to the water supply in the ancient Greek poleis of the Northern Black Sea region.

The settlement of Vilino (Rassadnoie) could become one of the basic objects for developing chronological issues, defining the borders of the Chersonesus state, trade relations with the Mediterranean, Greek-barbarian relations in Western Crimea in the era of Hellenistic Greece and Roman Period, etc.

Keywords: rainwater cistern, burial structure, ancient architecture 
Таблица 1

Керамика из заполнения цистерны

\begin{tabular}{|c|l|c|c|c|c|}
\hline №№ & \multicolumn{1}{|c|}{ Типы керамики } & $\begin{array}{l}\text { Профильных } \\
\text { частей }\end{array}$ & Стенок & Всего & $\%$ \\
\hline 1 & Амфоры & 72 & 294 & 366 & 67,4 \\
\hline 2 & $\begin{array}{l}\text { Краснолаковая по- } \\
\text { суда }\end{array}$ & 25 & 26 & 51 & 9,4 \\
\hline 3 & $\begin{array}{l}\text { Чернолаковая кера- } \\
\text { мика }\end{array}$ & 2 & 1 & 3 & 0,5 \\
\hline 4 & Гончарная посуда & 31 & 21 & 52 & 9,6 \\
\hline 5 & Лепная посуда & 16 & 36 & 52 & 9,6 \\
\hline 6 & $\begin{array}{l}\text { Светильники и гру- } \\
\text { зила }\end{array}$ & 2 & & 2 & 0,3 \\
\hline 7 & $\begin{array}{l}\text { Черепица (Херсонес } \\
\text { и Синопа) }\end{array}$ & 5 & 12 & 17 & 3,2 \\
\hline & $\mathbf{1 5 3}$ & $\mathbf{3 9 0}$ & $\mathbf{5 4 3}$ & $\mathbf{1 0 0}$ \\
\hline
\end{tabular}

Таблица 2

Центры амфорной тары из заполнения цистерны

\begin{tabular}{|c|c|c|c|c|c|}
\hline №№ & Центр & $\begin{array}{c}\text { Профильных } \\
\text { частей }\end{array}$ & Стенок & Всего & $\%$ \\
\hline 1 & Херсонес & 20 & 125 & 145 & 39,6 \\
\hline 2 & Синопа & 23 & 94 & 117 & 31,9 \\
\hline 3 & Родос & 10 & 12 & 22 & 6,0 \\
\hline 4 & $\begin{array}{l}\text { Светлоглиняные уз- } \\
\text { когорлые }\end{array}$ & 3 & 17 & 20 & 5,5 \\
\hline 5 & $\begin{array}{l}\text { Сдвухствольными } \\
\text { ручками }\end{array}$ & 2 & 6 & 8 & 2,2 \\
\hline 6 & Кос & --- & 3 & 3 & 0,9 \\
\hline 7 & Книд & 1 & 3 & 4 & 1,2 \\
\hline 8 & Боспор & 1 & 3 & 4 & 1,2 \\
\hline \multirow[t]{6}{*}{9} & $\begin{array}{l}\text { Неопределенные } \\
\text { центры }\end{array}$ & & & & \\
\hline & Светлоглиняные & 9 & 18 & 27 & 7,4 \\
\hline & Красноглиняные & 1 & 8 & 9 & 2,5 \\
\hline & Коричневоглиняные & 1 & 5 & 6 & 1,6 \\
\hline & $\begin{array}{l}\text { C pюмковидной } \\
\text { ножкой }\end{array}$ & 1 & --- & 1 & \\
\hline & & 72 & 294 & 366 & \\
\hline
\end{tabular}


Таблица 3

Типы и центры профильных частей амфор из цистерны

\begin{tabular}{|c|c|c|c|c|c|}
\hline $\begin{array}{l}\text { № } \\
\text { № }\end{array}$ & $\begin{array}{c}\text { Обозначение } \\
\text { типа }\end{array}$ & Дата & Литература & $\begin{array}{c}\text { Тип ам- } \\
\text { форы }\end{array}$ & $\begin{array}{l}\text { Номер } \\
\text { ри- } \\
\text { сунка }\end{array}$ \\
\hline 1 & $\begin{array}{l}\text { Узкогорлые } \\
\text { светлоглинян- } \\
\text { ные } \\
\end{array}$ & $\begin{array}{l}\text { Вторая, третья } \\
\text { четверть - конец } \\
\text { II в. н.э. } \\
\end{array}$ & Внуков 2006. С. 167. & тип C-IVC & 14,6 \\
\hline 2 & $\begin{array}{l}\text { Узкогорлые } \\
\text { светлоглинян- } \\
\text { ные } \\
\end{array}$ & $\begin{array}{l}\text { Вторая, } \\
\text { четверть - конья } \\
\text { II в. н.э. } \\
\end{array}$ & Внуков 2006. С. 167. & C-IVC & 9,13 \\
\hline 3 & Синопские & II в. до н.э. & $\begin{array}{l}\text { Монахов 2003. С. } 153- \\
155, \text { табл. } 104,105,1- \\
4 .\end{array}$ & III D & 10,1 \\
\hline 4 & Синопские & II в. до н.э. & $\begin{array}{l}\text { Монахов 2003. С. } 153- \\
155, \text { табл. } 104,105,1- \\
4 .\end{array}$ & III D & 7,9 \\
\hline 4 & Синопские & $\begin{array}{l}\text { конец } 80-x-\text { на- } \\
\text { чало } 50-x \text { гг. III в. } \\
\text { до н.э. }\end{array}$ & $\begin{array}{l}\text { Граков, 1928. табл. 6; } \\
\text { 7; Кац 2007. С. } 435 .\end{array}$ & $\begin{array}{l}\text { Гести- } \\
\text { эй } 1 \quad \text { (V } \\
\text { МГ, под- } \\
\text { группа A }\end{array}$ & 8,6 \\
\hline 5 & Родосские & $\begin{array}{l}\text { Конец III в. до н.э. } \\
\text { - II в. до н.э. }\end{array}$ & $\begin{array}{l}\text { Абрамов 2003. С. } 42 \text {, } \\
\text { рис. } 43 .\end{array}$ & $\begin{array}{l}\text { тип II A- } \\
1 \text {, IIA-6 }\end{array}$ & 9,2 \\
\hline 6 & Херсонесские & $\begin{array}{l}\text { Последняя треть } \\
\text { IV в. до н.э. - пер- } \\
\text { вая половина III в. } \\
\text { до н.э }\end{array}$ & $\begin{array}{l}\text { Монахов 1989. табл. } \\
\text { XVIII, XX, C. } 140 .\end{array}$ & III & 7,8 \\
\hline 8 & Книдские & $\begin{array}{l}\text { Середина III в. до } \\
\text { н.э. - первая по- } \\
\text { ловина I в. н.э. }\end{array}$ & Монахов 2003. С. 109. & IIF, IIG & 10,3 \\
\hline 9 & Синопские & $\begin{array}{l}\text { Середина III в. до } \\
\text { н.э. - середина } \\
\text { II в. до н.э. }\end{array}$ & $\begin{array}{l}\text { Монахов 2003. С. 153- } \\
\text { 154, табл. } 104 .\end{array}$ & III C & 10,2 \\
\hline 12 & $\begin{array}{l}\text { Узкогорлые } \\
\text { светлоглинян- } \\
\text { ные } \\
\end{array}$ & Конец I-II в. н.э. & Внуков 2006. С. 167. & C-IVC & 9.11 \\
\hline 13 & Херсонесские & $\begin{array}{l}\text { Первая треть III в. } \\
\text { до н.э. - вторая } \\
\text { четверть II в. до } \\
\text { н.э. }\end{array}$ & $\begin{array}{l}\text { Монахов 2003. C. 62- } \\
\text { 63. Табл. XIV. }\end{array}$ & II B & 10,4 \\
\hline 20 & Синопские & ІІ в до н.э. & $\begin{array}{l}\text { Монахов 2003. С. } 153- \\
155, \text { табл. } 104,105,1- \\
4 .\end{array}$ & III D & 12,9 \\
\hline 27 & Синопские & $\begin{array}{l}\text { Середина III в. до } \\
\text { н.э. - середина } \\
\text { II в. до н.э. }\end{array}$ & $\begin{array}{l}\text { Монахов 2003. С. 153- } \\
\text { 154, табл. } 104 .\end{array}$ & III C & 12,10 \\
\hline 28 & $\begin{array}{l}\text { Светлоглиня- } \\
\text { ные }\end{array}$ & $\begin{array}{l}\text { вторая, } \text { начало } \\
\text { третьей четверти } \\
\text { I в. н.э; 60-е гг. I в. } \\
\text { н.э. }\end{array}$ & $\begin{array}{l}\text { Внуков 2003, рис. } 45 \text {; } \\
2006 . \text { С. } 167 .\end{array}$ & $\begin{array}{l}\text { C-IVA1 C- } \\
\text { IVA2 }\end{array}$ & 11.3 \\
\hline
\end{tabular}




\begin{tabular}{|c|c|c|c|c|c|}
\hline 29 & Херсонесские & $\begin{array}{l}\text { Последняя треть } \\
\text { IV в. до н.э. - пер- } \\
\text { вая половина III в. } \\
\text { до н.э. }\end{array}$ & $\begin{array}{l}\text { Монахов 1989. С. } 42- \\
59 .\end{array}$ & I & 11,1 \\
\hline 30 & Родосские & II в. до н.э & Монахов 2003. С. 120. & I-E-2 & 11.13 \\
\hline 31 & $\begin{array}{l}\text { Красноглиня- } \\
\text { ные.с двух- } \\
\text { ствольными } \\
\text { ручками }\end{array}$ & $\begin{array}{l}\text { Конец I в. до н.э. - } \\
\text { первая половина } \\
\text { I в. н.э. }\end{array}$ & $\begin{array}{l}\text { Абрамов 1993. С. 44- } \\
45 \text {, рис. } 48 .\end{array}$ & $\begin{array}{l}\text { I в. до н.э. } \\
\text { - І в. н.э. }\end{array}$ & 12,4 \\
\hline 32 & Родосские & ок. 119 г. до н.э. & $\begin{array}{l}\text { (V ХГ, подгруппа Vc) } \\
\text { [Finkielsztejn, 2001; } \\
\text { Кац, 2007] }\end{array}$ & $\begin{array}{l}\text { EПI } \\
\text { EYANOP } \\
\text { AI }\end{array}$ & 8,5 \\
\hline 34 & Синопские & II в. до н.э. & $\begin{array}{l}\text { Монахов С. 154-155, } \\
\text { табл. 105, 1-4. }\end{array}$ & IIID & 8,5 \\
\hline
\end{tabular}

Таблица 4

Типы профильных частей краснолаковой посуды з цистерны

\begin{tabular}{|c|c|c|c|c|c|c|}
\hline $\begin{array}{l}\text { № } \\
\text { № }\end{array}$ & $\begin{array}{c}\text { Тип } \\
\text { посуды }\end{array}$ & Дата & Литература & Тип & $\begin{array}{l}\text { Номер } \\
\text { рисунка }\end{array}$ & $\begin{array}{c}\text { Диа- } \\
\text { метр } \\
\text { венца }\end{array}$ \\
\hline 1 & Канфар & I в. н.Э. & $\begin{array}{l}\text { Труфанов } 2009 . \\
\text { С. } 160, \text { рис. } 22,3,5 .\end{array}$ & 2 & & $9,2 \mathrm{~cm}$ \\
\hline 2 & Чашка & $\begin{array}{l}\text { Конец I в. } \\
\text { н.э. - II в. } \\
\text { Н.э. }\end{array}$ & $\begin{array}{l}\text { Труфанов } 2009 . \\
\text { С. 154, рис. 19, 4-7. }\end{array}$ & $\begin{array}{l}\text { 2, вари- } \\
\text { ант } 1\end{array}$ & 13,2 & \\
\hline 3 & Чашка & $\begin{array}{l}\text { Последняя } \\
\text { четверть } \\
\text { I в. н.э. }\end{array}$ & $\begin{array}{l}\text { Журавлев } 2007 . \\
\text { С. } 376, \text { рис. } 5 .\end{array}$ & $\begin{array}{c}\text { Форма } \\
16,3\end{array}$ & 14,3 & $9,3 \mathrm{~cm}$ \\
\hline 5 & чашки & $\begin{array}{l}\text { Конец I в. } \\
\text { н.э. - II в. } \\
\text { н.э. }\end{array}$ & $\begin{array}{l}\text { Труфанов } 2009 . \\
\text { С. 154, рис. 19, 4-7. }\end{array}$ & $\begin{array}{l}\text { 2, вари- } \\
\text { ант } 1\end{array}$ & 14,2 & \\
\hline 7 & тарелки & $\begin{array}{l}\text { Середина } \\
\text { I в. н.э. - } \\
\text { первая чет- } \\
\text { верть II в. } \\
\text { н.э. }\end{array}$ & $\begin{array}{l}\text { Труфанов } 2009 . \\
\text { С. 153, рис. 15, } 2 .\end{array}$ & $\begin{array}{c}\text { PS (Пон- } \\
\text { тийская } \\
\text { сигилат- } \\
\text { та) }\end{array}$ & 13,3 & \\
\hline 8 & тарелки & $\begin{array}{ll}\text { Конец } & \text { I- } \\
\text { II в. н.э. } & \end{array}$ & $\begin{array}{ll}\text { Труфанов } & 1997 . \\
\text { C. } 181-192 . & \end{array}$ & $3-E-3$ & 13,1 & $13.0 \mathrm{~cm}$ \\
\hline 9 & тарелки & $\begin{array}{l}\text { Середина } \\
\text { I в. н.э. - } \\
\text { первая чет- } \\
\text { верть II в. } \\
\text { н.э. }\end{array}$ & $\begin{array}{l}\text { Труфанов } 2009 . \\
\text { С. 153, рис 18, } 8 .\end{array}$ & $\begin{array}{c}\text { PS (Пон- } \\
\text { тийская } \\
\text { сигилат- } \\
\text { та) }\end{array}$ & 12,5 & $19.0 \mathrm{~cm}$ \\
\hline 10 & миски & $\begin{array}{l}\text { Конец } \text { II в. } \\
\text { н.э. - пер- } \\
\text { вая поло- } \\
\text { вина III в. } \\
\text { н.э. }\end{array}$ & $\begin{array}{l}\text { Труфанов } 2009 \\
\text { С. } 153, \text { рис. } 17,1,4 .\end{array}$ & II & 13,4 & $14,0 \mathrm{~cm}$ \\
\hline
\end{tabular}


Таблица 5

Типы бус из цистерны

\begin{tabular}{|c|c|c|c|c|c|}
\hline $\begin{array}{l}\text { № } \\
\text { № }\end{array}$ & $\begin{array}{l}\text { Материал } \\
\text { форма бус }\end{array}$ & Дата & $\begin{array}{c}\text { Основание } \\
\text { для определения }\end{array}$ & $\begin{array}{c}\text { Тип } \\
\text { бусины }\end{array}$ & $\begin{array}{l}\text { Номер } \\
\text { рис. }\end{array}$ \\
\hline 1 & $\begin{array}{l}\text { Округлые глазча- } \\
\text { тые }\end{array}$ & II в. до н.э. & Алексеева 1975. С. 59. & $26 a$ & 17,15 \\
\hline 2 & $\begin{array}{l}\text { Округлые глазча- } \\
\text { тые }\end{array}$ & $\begin{array}{l}\text { I в. до н.э. - } \\
\text { І в. Н. э. }\end{array}$ & Алексеева 1975. С. 67. & 68 & 17,14 \\
\hline 3 & $\begin{array}{l}\text { Сердоликовые ок- } \\
\text { ругло цилиндриче- } \\
\text { ские }\end{array}$ & $\begin{array}{l}\text { III в. до н.э. - } \\
\text { первые века }\end{array}$ & Алексеева 1982. С. 16. & $3 б$ & 17,13 \\
\hline 4 & $\begin{array}{l}\text { Округлые глазча- } \\
\text { тые }\end{array}$ & $\begin{array}{lr}\text { II в. до } & \text { н.э.- } \\
\text { первая } & \text { по- } \\
\text { ловина } & \text { II в. } \\
\text { н.э. } & \\
\end{array}$ & Алексеева 1975. С. 66. & $60 a$ & 16,22 \\
\hline 5 & $\begin{array}{l}\text { Бочковидные поли- } \\
\text { хромные }\end{array}$ & & Алексеева 1978. С. 44. & $203 a$ & 16,24 \\
\hline 6 & $\begin{array}{l}\text { Фаянсовые ребри- } \\
\text { стые }\end{array}$ & I-II вв. н.э. & Алексеева 1975. С. 34. & $16 \Gamma$ & 16,25 \\
\hline 7 & $\begin{array}{l}\text { Фрагмент глазча- } \\
\text { той } \\
\end{array}$ & & Алексеева 1975. С. 68. & $79 ?$ & 16,14 \\
\hline 8 & Стекло белое глухое & $\begin{array}{l}\text { Первые века } \\
\text { н.э. }\end{array}$ & Алексеева 1978.С. 65. & 21 & 16,18 \\
\hline 9 & $\begin{array}{l}\text { Стекло с металли- } \\
\text { ческой прокладкой }\end{array}$ & $\begin{array}{l}\text { Первые века } \\
\text { н.э. }\end{array}$ & Алексеева 1978. С. 29. & 1 & 16.20 \\
\hline 10 & $\begin{array}{l}\text { Стекло синее про- } \\
\text { зрачное }\end{array}$ & I-II вв. н.э. & $\begin{array}{l}\text { Алексеева 1978. С. 64- } \\
65 .\end{array}$ & 15 & 16,23 \\
\hline 11 & $\begin{array}{l}\text { Стекло зеленое про- } \\
\text { зрачное }\end{array}$ & $\begin{array}{l}\text { Вторая пол. } \\
\text { I - II вв. н.э }\end{array}$ & Алексеева 1978. С. 67. & 63 & 16,19 \\
\hline 12 & $\begin{array}{l}\text { Стекло голубое глу- } \\
\text { хое }\end{array}$ & I-II вв. н.э. & Алексеева 1978. & 31 & 16,21 \\
\hline 13 & Стекло белое глухое & $\begin{array}{l}\text { Первые века } \\
\text { н.э. }\end{array}$ & Алексеева 1978. С. 65. & 21 & 16,26 \\
\hline 14 & Стекло белое глухое & $\begin{array}{l}\text { Первые века } \\
\text { н.э. }\end{array}$ & Алексеева 1978. С. 65. & 21 & 17,21 \\
\hline 15 & Стекло белое глухое & $\begin{array}{l}\text { Первые века } \\
\text { н.э }\end{array}$ & Алексеева 1978. С. 65. & 21 & 17,10 \\
\hline 16 & Стекло синее глухое & I-II вB. н.э. & Алексеева 1978. С. 68. & 93 & 17,6 \\
\hline 17 & $\begin{array}{l}\text { Стекло с металли- } \\
\text { ческой прокладкой }\end{array}$ & $\begin{array}{l}\text { Первые века } \\
\text { н.э }\end{array}$ & Алексеева 1978. С. 29. & $1 \mathrm{a}$ & 17,8 \\
\hline 18 & $\begin{array}{l}\text { Стекло с металли- } \\
\text { ческой прокладкой }\end{array}$ & $\begin{array}{l}\text { Первые века } \\
\text { н.э }\end{array}$ & Алексеева 1978. С. 30. & 26 & 17,7 \\
\hline 19 & $\begin{array}{l}\text { Стекло с металли- } \\
\text { ческой прокладкой }\end{array}$ & $\begin{array}{l}\text { Первые века } \\
\text { н.э }\end{array}$ & Алексеева 1978. С. 29. & 16 & 17,9 \\
\hline 20 & $\begin{array}{l}\text { Стекло с продоль- } \\
\text { но-полосатым ор- } \\
\text { наментом }\end{array}$ & & Алексеева 1978. С. 43 & 195 & 17,11 \\
\hline 21 & $\begin{array}{l}\text { Стекло красное глу- } \\
\text { хое }\end{array}$ & II-III вв. н.э. & Алексеева 1978. С. 66. & 47 & 17,3 \\
\hline
\end{tabular}




\begin{tabular}{|c|c|c|c|c|c|}
\hline 22 & Гагат & I-II вв. н.э. & $\begin{array}{l}\text { Алексеева 1978. С. 13- } \\
14 .\end{array}$ & 26 & 17,2 \\
\hline 23 & Гагат & I-II вB. н.э. & Алексеева 1978. С. 14. & $27 a$ & 17,2 \\
\hline 24 & $\begin{array}{l}\text { Волнисто-попереч- } \\
\text { но-линейным ор- } \\
\text { наментом }\end{array}$ & $\begin{array}{l}\text { II-IV вв. до } \\
\text { н.э. }\end{array}$ & Алексеева 1978. С. 52. & $313-325$ & 17.4 \\
\hline 25 & $\begin{array}{l}\text { Бронза цилиндри- } \\
\text { ческая }\end{array}$ & I-II вв. н.э. & Алексеева 1982. С. 23. & 5 & 17,1 \\
\hline 26 & Фаянс & I-II вB. н.Э & Алексеева 1975. С. 31. & $3 \Gamma$ & 17,5 \\
\hline 27 & $\begin{array}{l}\text { Стекло белое глухое } \\
\text { с черной поперчной } \\
\text { полосой }\end{array}$ & & Алексеева 1978. С. 44 & $203 a$ & 17,12 \\
\hline 28 & $\begin{array}{l}\text { Стекло белое глухое } \\
\text { ребристые }\end{array}$ & I-II вB. н.Э & Алексеева 1978. С. 71. & 142 & $\begin{array}{c}17,17,1 \\
8 \\
\end{array}$ \\
\hline 29 & Стекло белое глухое & $\begin{array}{l}\text { Первые века } \\
\text { н.э }\end{array}$ & Алексеева 1978. С. 65. & 21 & 17,21 \\
\hline 30 & $\begin{array}{l}\text { Сердоликовые ок- } \\
\text { ругло цилиндриче- } \\
\text { ские }\end{array}$ & $\begin{array}{l}\text { III в. до н.э. - } \\
\text { первые века }\end{array}$ & Алексеева 1982. С. 16. & 3б & 17,16 \\
\hline 31 & Гагат & I в. Н.Э. & Алексеева 1978. & $27 a$ & 17,2 \\
\hline 32 & Гагат & I-III вВ. н.э & Алексеева 197. С. 12. & 8 8б & 17,2 \\
\hline 33 & $\begin{array}{l}\text { Стекло с металли- } \\
\text { ческой прокладкой }\end{array}$ & Первые века & Алексеева 1978. С. 29. & 16 & 17,22 \\
\hline 34 & $\begin{array}{l}\text { Стекло с металли- } \\
\text { ческой прокладкой }\end{array}$ & Первые века & Алексеева 1978. С. 29. & $1 \mathrm{a}$ & 17.27 \\
\hline 35 & $\begin{array}{l}\text { Стекло с металли- } \\
\text { ческой прокладкой }\end{array}$ & Первые века & Алексеева 1978. С. 30. & 26 & 17,24 \\
\hline 36 & $\begin{array}{l}\text { Стекло с металли- } \\
\text { ческой прокладкой }\end{array}$ & $\begin{array}{l}\text { I в. до н.э. - } \\
\text { I в. Н.э. }\end{array}$ & Алексеева 1978. С. 31. & 10 & 17,25 \\
\hline 37 & Фаянс & I-II вВ. н.э. & Алексеева 1975. С. 33. & 11 & 17,23 \\
\hline 38 & $\begin{array}{l}\text { Стекло, цилиндри- } \\
\text { ческие с поперечно- } \\
\text { линейным и пери- } \\
\text { стым орнаментом }\end{array}$ & II-I вВ. до н.э. & Алексеева 1978. С. 53. & 341 & 17,30 \\
\hline 39 & Стекло белое глухое & $\begin{array}{l}\text { Первые века } \\
\text { н.э. }\end{array}$ & Алексеева 1978. С. 65. & 21 & 17,29 \\
\hline 40 & $\begin{array}{l}\text { Стекло синее про- } \\
\text { зрачное }\end{array}$ & $\begin{array}{l}\text { Первые века } \\
\text { н.э. }\end{array}$ & $\begin{array}{l}\text { Алексеева 1978. С. 64- } \\
65 .\end{array}$ & 15 & 17,28 \\
\hline 41 & $\begin{array}{l}\text { Стекло с светло- } \\
\text { зеленое прозрачное }\end{array}$ & I-II вВ. н.э. & Алексеева 1978. С. 65. & 17 & 16,16 \\
\hline 42 & $\begin{array}{l}\text { Стекло безцветное } \\
\text { прозрачное, ребри- } \\
\text { стые }\end{array}$ & $\begin{array}{l}\text { III-I вв. до } \\
\text { н.э. }\end{array}$ & Алексеева 1978. С. 71. & 152 & 16,15 \\
\hline 43 & Стекло синее глухое & I-III вВ. н.э. & $\begin{array}{l}\text { Алексеева 1978. С. 65- } \\
66 .\end{array}$ & 29 & 16,27 \\
\hline 44 & Стекло белое глухое & $\begin{array}{l}\text { Первые века } \\
\text { н.э. }\end{array}$ & Алексеева 1978. С. 65. & 21 & 16,28 \\
\hline 45 & $\begin{array}{l}\text { Стекло с металли- } \\
\text { ческой прокладкой }\end{array}$ & $\begin{array}{l}\text { Первые века } \\
\text { н.э. }\end{array}$ & Алексеева 1978. С. 29. & $1 \mathrm{a}$ & 16,29 \\
\hline 46 & $\begin{array}{l}\text { Стекло с металли- } \\
\text { ческой прокладкой }\end{array}$ & $\begin{array}{l}\text { І в. н.э. - на- } \\
\text { чало III в. н.э. }\end{array}$ & Алексеева 1978. С. 25. & 22 & 16,35 \\
\hline
\end{tabular}




\begin{tabular}{|c|c|c|c|c|c|}
\hline 47 & Гагат & $\begin{array}{l}\text { Первые века } \\
\text { н.э. }\end{array}$ & Алексеева 1978. С. 17. & 62 & 16,30 \\
\hline 48 & Фаянс & I-II вВ. н.э. & Алексеева 1978. С. 31. & $3 \Gamma$ & 16,32 \\
\hline 49 & $\begin{array}{l}\text { Сердоликовые ок- } \\
\text { ругло цилиндриче- } \\
\text { ские }\end{array}$ & $\begin{array}{l}\text { III в. до н.э. - } \\
\text { первые века }\end{array}$ & Алексеева 1982. С. 16. & Зб & 16,33 \\
\hline 50 & $\begin{array}{l}\text { Стекло с пятнистым } \\
\text { орнаментом }\end{array}$ & & Алексеева 1975. С. 57. & 9 & 16,34 \\
\hline 51 & $\begin{array}{l}\text { Стекло с продоль- } \\
\text { но-полосатым ор- } \\
\text { наментом }\end{array}$ & & Алексеева 1978. С. 43. & 195 & 16,31 \\
\hline 52 & $\begin{array}{l}\text { Пронизь бронзовая } \\
\text { спиралевидная }\end{array}$ & I-II вВ. н.э. & Алексеева 1982. С. 26. & 31 & 16,7 \\
\hline
\end{tabular}

